\title{
Do Conglomerate Firms Allocate Resources Inefficiently?
}

\author{
Vojislav Maksimovic \\ Gordon Phillips* \\ Robert H. Smith School of Business \\ University of Maryland \\ First draft: February 14, 1998 \\ Current version: February 5, 1999 \\ Comments Welcome
}

\footnotetext{
*A previous draft was circulated and presented with the title: Optimal Firm Size and the Growth of Conglomerate and Single-Industry Firms. This research was supported by NSF Grant \#SBR-9709427. We wish to thank John Graham, Robert Hauswald, Anjan Thakor, Sheridan Titman, Haluk Unal and seminar participants at Carnegie Mellon, Harvard University, Illinois, Indiana, Maryland, Michigan, Ohio State, University of Pennsylvania, Virginia Polytechnic University, The 1999 AFA meetings, the National Bureau of Economic Research, and the 1998 Finance and Accounting Conference at NYU for their comments. We also wish to thank researchers at the Center for Economic Studies for comments and their help with the data used in this study. Maksimovic can be reached by email at vmax@mbs.umd.edu, Internet homepage: http://www.mbs.umd.edu/Finance/vmax/. Phillips can be reached by email at GPhillips@mbs.umd.edu, Internet homepage: http://www.mbs.umd.edu/Finance/gphillips/. The research was conducted at the Center for Economic Studies, U.S. Bureau of the Census, Department of Commerce. The authors alone are responsible for the work and any errors or omissions.
} 


\title{
Do Conglomerate Firms Allocate Resources Inefficiently?
}

\begin{abstract}
We develop a profit-maximizing neoclassical model of optimal firm size and growth across different industries. The model predicts how conglomerate firms will allocate resources across divisions over the business cycle and how their responses to industry shocks will differ from those of single-segment firms. We test our model and find that growth of conglomerate and single-segment firms is related to fundamental industry factors and individual firm-segment productivity consistent with our simple neoclassical theory. Conglomerates grow less in a particular segment if their other segments are more productive and if their other segments experience a larger positive demand shock. We find that the growth rates of peripheral segments are very sensitive to relative productivity and that conglomerates sharply cut the growth of unproductive peripheral segments. We do find some evidence consistent with agency problems for conglomerate firms that are broken up. However, the majority of conglomerate firms exhibit growth across business segments that is consistent with optimal behavior.
\end{abstract}




\section{Do Conglomerate Firms Allocate Resources Inefficiently?}

Several recent academic papers and the business press claim that conglomerate firms destroy value and do a poor job of investing across business segments. ${ }^{1}$ Explanations for this underperformance share the idea that there is an imperfection either in firm governance (agency theory) or in financial markets (incorrect valuation of firm industry segments). These studies implicitly assume that the conglomerates and single-industry firms possess similar ability to compete, and that they differ mainly in that conglomerates have chosen to operate in more than one industry. However, firms do differ in their ability to exploit market opportunities. ${ }^{2}$ In the absence of a benchmark model of how these differences affect firms' to invest in different divisions, it is not clear whether earlier studies' results are driven by the underlying comparative advantages of different types of firms or by one or more of the postulated explanations.

In our paper, we analyze how firms' size and growth across industries in the absence of market imperfections, using a neoclassical model based on Lucas (1978). ${ }^{3}$ In our model a conglomerate discount caused by differences in underlying firm ability can arise endogenously. We obtain predictions on how firms should allocate resources optimally across business segments in the absence of agency problems. These predictions differ from predictions arising from agency models predicting inefficient investment. We test these predictions by examining the growth and efficiency of over 50,000 firms and their business segments using plant-level data for the period 1975 to 1992. By using this plant-level data we can determine how the growth of a multiple-segment firm depends on each segment's efficiency, the returns-to-scale in the industries in which the firm operates, and relative demand in those industries. We find that conglomerate resource allocation is generally consistent with our model of efficient allocation of resources across business segments.

Our model shows that firms with a comparative advantage, arising from managerial skill in producing within an industry, have higher growth and attain a larger size in that

\footnotetext{
${ }^{1}$ Lang and Stulz (1994), Berger and Ofek (1995) and Comment and Jarrell (1995) document a conglomerate discount in the stock market and low returns to conglomerate firms. Rajan, Servaes, and Zingales (1997) and Scharfstein (1997) examine conglomerate investment across different business segments. Lamont (1997) and Shin and Stulz (1997) examine the relation of investment to cash flow for conglomerate industry segments. For one example from the business press see "Then There Will be Two," New York Times, business section, October 13, 1998.

${ }^{2}$ Peters and Waterman (1982), Schmalensee (1985), and many other authors, have noted that firms differ even within the same markets. Lang and Stulz (1994) note that firms that become conglomerates may differ from those that stay within one industry.

${ }^{3}$ Firm growth has been examined in other contexts by Evans (1987) and Hall (1987). They test whether the relationship between firm growth and firm size is constant for different types of firms, as predicted by Gibrat's Law.
} 
industry. As a firm's returns within an industry diminish, the firm limits its growth within the industry and moves into other industries. The optimal number and size of industry segments a firm operates depends on its comparative advantage across industries. Firms that are very productive in a specific industry have higher opportunity costs of diversifying. Thus, in equilibrium, if a high level of managerial skill is industry specific, single-segment firms are more productive than conglomerates in the same industries. If managerial skill is not industry specific, conglomerates may be more productive then single-segment firms. Comparative advantage also implies that the larger divisions of conglomerates are relatively more efficient than their smaller divisions. ${ }^{4}$

The model also predicts that the effect of demand shocks on the growth of a conglomerate's division depends on its own productivity. The same positive shock that causes more productive firms to increase their market share also can cause less productive firms to sell capacity and decrease their size. Thus, inefficient and efficient firms should optimally invest differently when industry conditions change. This result implies that empirical tests of how conglomerates invest in response to changes in industry prospects could be misspecified if they do not control for the productivity of the firm's individual divisions.

A key prediction of the model is that demand shocks faced by a segment of a conglomerate firm affect the growth rates of other segments, and do so even in the absence of agency costs and financial market imperfections. If a division is less (more) productive than singlesegment firms in its industry, a positive demand shock in a division increases (decreases) the growth rates of other segments. Because models that postulate an important role for agency costs and internal capital markets imply a different relation, this prediction can be used to distinguish empirically between these models and our neoclassical model.

Our empirical analysis shows that conglomerate firms are less productive than singlesegment firms of a similar size. This is consistent with the finding of a conglomerate discount by Lang and Stulz (1994) and Berger and Ofek (1995). It is also consistent with our model of optimal resource allocation of firms.

The comparison of productivity within conglomerates exhibits two strong empirical regularities. Larger segments are more productive than smaller segments. This is consistent with maximizing behavior. The differences in productivity across segments also suggest that for most firms managerial talent has an industry-specific component. However, when

\footnotetext{
${ }^{4}$ Our model analyzes how comparative advantage in the product market may leads some firms to become conglomerates. Models that predict that firms become conglomerates to benefit from more efficient capital allocation include Matsusaka and Nanda (1996), Stein (1997) and Fluck and Lynch (1996). Hubbard and Palia (1998) present evidence from the 1960s that is consistent with these models. Hadlock, Ryngaert, and Thomas (1998) provide more recent evidence consistent with a capital allocation benefit of conglomerates.
} 
divisions within a conglomerate are ranked by size, and compared with equally ranked divisions of other conglomerates, we find a positive relation between the segment's productivity and the number of industries in which the conglomerates operate. This suggests that those conglomerates that operate in many segments have a higher level of general ability than conglomerates that operate in a few segments.

While these comparisons of the productivities within conglomerate firms are consistent with a neoclassical model, they might also occur if conglomerates suboptimally expand into industries in which they have a low level of specific skill. To discriminate between these two possibilities, we examine how conglomerates grow in different industries. We test whether the growth rate of a division is related to the efficiency of the conglomerate's divisions and how growth changes in response to industry shocks.

The empirical tests show that the growth of both more- and less-productive firm segments is related to efficiency and fundamental industry factors, both in recession and expansion periods. Divisions of conglomerates grow more slowly if the conglomerates other divisions are efficient in their industries, and faster if their other divisions are inefficient. The growth of peripheral divisions, in particular, is strongly related to their productivity. ${ }^{5}$

Changes in a segment's growth rate in response to industry shocks in other segments are consistent with the neo-classical model. If a conglomerate's industry segment is less productive compared with other firms in its industry, a positive demand shock in that segment increases the growth rates of the conglomerate's other segments. The evidence is not consistent with the hypothesis that conglomerates expand unproductive industry segments or protect them from recessions by using cash flows from other divisions.

We do find some evidence to indicate that some conglomerates may have agency problems. We examine conglomerates that are broken up into single-segment firms during the 1980s. ${ }^{6}$ We find that the growth of these broken-up conglomerates is not consistent with our model of optimal growth. However, even for these firms, we find no evidence that conglomerates subsidize the growth of inefficient divisions. We also find that the growth rates of firms that remain conglomerates, which are the majority of conglomerates, are strongly sensitive to industry variables and productivity. These findings are consistent with optimal behavior. The results indicate that the surviving conglomerates grow efficiently across their

\footnotetext{
${ }^{5}$ This high sensitivity of peripheral-segment growth to productivity is also consistent with a capital allocation motive for conglomerates. Conglomerates may be experimenting by entering new industries. If they find out that they have a comparative advantage in that industry they expand, otherwise they contract their operations.

${ }^{6}$ See Lang, Poulsen, and Stulz (1995), Comment and Jarrell (1995), and Berger and Ofek (1997) for an analysis of the recent increases in firm restructuring.
} 
business segments.

Our work follows prior papers by Lang and Stulz (1994) and Berger and Ofek (1995), who show that conglomerate firms have a discount in the stock market relative to single-segment firms. Comment and Jarrell (1995) document that stock market returns to conglomerate firms are lower. Berger and Ofek (1995) and Comment and Jarrell (1995) explain their findings by appealing to agency theories that predict a misallocation of capital as firms allocate capital to divisions that are under-performing. Lang and Stulz (1994) note that poorly performing firms may choose to become conglomerates. However, they find only limited evidence for this hypothesis, and their data does not permit them to examine how productivity varies by segment. Lamont (1997) and Shin and Stulz (1997) examine how investment is related to industry Tobin's q and cash flow. Scharfstein (1997) finds that conglomerate firms invest more in low- $q$ industries if managerial ownership is low. Rajan, Servaes, and Zingales (1998) find that the extent of firm investment in divisions in low- $q$ industries is related to the diversity of investment opportunities across divisions. However, there is one large limitation to these studies. These studies proxy for investment opportunities for conglomerate firms using an industry Tobin's $q$. Using an industry Tobin's $q$ implicitly assumes that all firms, conglomerates and single-segment firms, have similar investment opportunities within an industry and should increase investment when the industry $q$ increases. ${ }^{7}$

Our analysis differs from earlier work on conglomerate firms as our model gives a benchmark for what growth should be, based on optimal firm size. We also measure efficiency at a disaggregated level. Thus, we can show that in certain instances, seemingly inefficient behavior by conglomerates is consistent with profit maximizing. In particular, we show that when firms' comparative advantage is taken into account, it can be optimal for less-efficient firms, when their industry experiences a positive demand shock, to invest outside of their industry.

The paper is organized as follows. Our framework is discussed in Section I. We discuss data and our methodology in Section II. Section III presents our results on growth and segment productivity for multiple-segment conglomerate and single-industry firms. Section IV concludes the paper.

\section{Optimal Firm Size and Growth over the Business Cycle}

We model firm focus and growth in a setting which allows firms to differ in their ability to realize revenues from operating plants. This differing ability arises because managerial

\footnotetext{
${ }^{7}$ Using industry $q$ in this way also increases measurement error associated with measuring true $q$, and biases the coefficient on $q$ toward zero, as shown by Whited (1998).
} 
talent varies across firms. ${ }^{8}$ As in Lucas (1978), managerial talent is a scarce resource and firm size within an industry adjusts to economize on managerial talent. ${ }^{9}$ Firms produce in industries in which they have a comparative advantage.

In our model, the extent to which managerial talent is industry-specific or can be applied in different industries determines whether or not firms should become conglomerates. Consider two specific cases. First, talent is industry-specific and firms that expand beyond their best industry incur a penalty in form of lower productivity in the other industries. As a result, firms that do have a special competency in an industry will be focused, whereas conglomerates will tend be less efficient firms whose managers are not the most talented in any one industry. Second, if talent in one industry is highly correlated with the ability to manage in other industries, conglomerates are more likely to be efficient firms whose managers have reached the point of diminishing returns in any single industry. We show that these two cases lead to different interpretations of the observed lower valuation for conglomerate firms in the stock market than for single-segment firms.

We also examine how the optimum size of a conglomerate's division changes in response to shocks to demand and other characteristics in its industry and in other industries. The model yields testable predictions on how optimal growth in different industries is affected both by the comparative advantage of the firm in each industry, and by changes in industry conditions. The predictions of our model differ from those of agency models. As a result, our model can be used to distinguish empirically between neoclassical and agency theories of conglomerate behavior.

\section{A. The model}

At all levels of managerial talent, firms face costs of supervision that increase with size. In determining their optimal growth, and whether to operate in more than one industry, firms trade-off marginal revenues against marginal costs of size. These trade-offs depend both on each firm's productivity and on demand conditions in each industry.

We assume that there is a population of $n$ firms that can operate in a maximum of two industries, we denote industry $A$ and industry $B$, respectively. All firms are assumed to be price-takers and to produce a homogeneous output. The level of demand in each industry is a random variable. Firms are endowed with industry-specific homogeneous production

\footnotetext{
${ }^{8}$ We interpret managerial talent broadly, including as talent the ability to manage a large organization. Our definition of managerial talent can also include firm-specific organizational capital or assets.

${ }^{9}$ So, for example, if there are very few highly talented managers and many incompetent potential managers, there will be a few big firms and perhaps many very small firms. On the other hand, if managerial talent is evenly spread around, there will be many moderately sized firms firms.
} 
capacity. There is one period and two dates: $t=1,2$.

At time $t=1$, the firms learn the actual realization of the next period's level of demand in each industry. A market for capacity opens in which firms can trade capacity units at a price $r$. Firms have a choice of using all their capacity to produce; scrapping some capacity and obtaining a salvage value; selling some capacity and using the remainder to produce; or buying more capacity and producing. Capacity may be purchased from and sold to other firms operating in the same industry, or from sources outside the industry. We assume that the total amount of capacity employed by the industry is $K=\alpha+\beta r$. Thus, total amount of capacity is a reduced form, reflecting the addition of new capacity (for high levels of $r$ ) and sales for scrap (for low levels of $r$ ). ${ }^{10}$

Finally, at time $t=2$, the firm realizes the cash flows. For simplicity, we assume that capacity has no salvage value at $t=2$.

In order to focus on the effect of differences in efficiency between firms on their optimal capacity in each industry, we make three key assumptions:

A1. In each industry, we assume that some firms operate plants more or less efficiently than do other firms. The efficiency with which any given firm operates plants can differ across industries.

Specifically, in each industry in which they operate, firms can be either high and low quality. High-quality firms, denoted by $H$, produce more output per unit of capacity than do low-quality firms, denoted by $L$.

A2. We assume that as their size increases beyond an efficient minimum scale, the firms face increasing costs of supervision and management

Thus, we assume that any given manager will do a better job of managing a small firm than a large firm. In this we follow Coase (1937) and Lucas (1978) in assuming diseconomies of scale within firms. Firms use the variable input, labor, together with capacity units, to produce output. As capacity increases beyond the minimum efficient scale, firms exhibit neoclassical decreasing returns-to-scale, so that their marginal costs increase with output.

For ease of exposition we assume that a firm that operates $k_{i}$ units of capacity in industry $i$ faces variable costs of $w_{i} k_{i}^{2}$ to operate each period, with $w_{i}$ is a positive constant that captures the cost of labor and other inputs that all firms use. We also assume that all firms face an additional coordination cost that depends on the total capacity operated in both industries, $v\left(k_{A}+k_{B}\right)^{2}$.

A3. The level of output demand is random. When demand uncertainty is resolved, the

\footnotetext{
${ }^{10}$ Thus, we assume that the supply of capacity is not perfectly elastic.
} 
price of capacity adjusts to clear the market.

To enable us to focus directly on the issues of interest, we assume that we also assume that the opportunity cost of capacity outside the two industries $A$ and $B$ is sufficiently low so that it is optimal for both high- and low-quality firms to operate for some feasible level of demand in both industries.

\section{A. The first-best equilibrium with conglomerate firms}

For the case of the conglomerate firm, the profit function is

$$
p_{A} d_{A} k_{A}^{c}+p_{B} d_{B} k_{B}^{c}-r_{A} k_{A}^{c}-r_{B} k_{B}^{c}-w_{A}\left(k_{A}^{c}\right)^{2}-w_{B}\left(k_{B}^{c}\right)^{2}-v\left(k_{A}^{c}+k_{B}^{c}\right)^{2} .
$$

In the conglomerate profit function we allow the conglomerate to have a differential productivity $d_{i}$, where $i=A$ or $B$ in each industry. Maximizing this expression for $k_{i}^{c}$ yields the optimal output of the conglomerate in each of the industries in which it operates.

$$
k_{i}^{c}=\frac{\left(d_{i} p_{i}-r_{i}\right)\left(v+w_{j}\right)-\left(d_{j} p_{j}-r_{j}\right) v}{2\left(w_{i} w_{j}+v\left(w_{i}+w_{j}\right)\right)}
$$

for $j$ not equal to $i$.

Proposition 1 (i)All other things being equal, if a conglomerate's segments differ in size, the main segments are more efficient than the peripheral segments. (ii) Firms that are relatively more efficient producing in one industry than the other one are focused. Firms in which the relative efficiency is similar are diversified.

\section{Proof}

For simplicity, assume that $w_{A}=w_{B}=w$. The difference between the output in industry $A$ and industry $B$ is $\left(\left(d_{A} p_{A}-r_{A}\right)-\left(d_{B} p_{B}-r_{B}\right)\right) w$. This quantity is positive (negative) if the conglomerate is more efficient industry $A$ than in industry $B$.

The derivative of the measure of the firm's focus, the Herfindahl index, with respect to $d_{A}$ is

$$
\frac{2 p_{A}\left(d_{B} p_{B}-r_{B}\right)(2 v+w)^{2}\left(\left(d_{A} p_{A}-r_{A}\right)-\left(d_{B} p_{B}-r_{B}\right)\right)}{w^{2}\left(\left(d_{A} p_{A}-r_{A}\right)+\left(d_{B} p_{B}-r_{B}\right)\right)^{3}} .
$$

Thus, an increase in $d_{A}$ increases focus if $\left(d_{A} p_{A}-r_{A}\right)>\left(d_{B} p_{B}-r_{B}\right)$, and decreases focus if $\left(d_{A} p_{A}-r_{A}\right)<\left(d_{B} p_{B}-r_{B}\right)$. Thus, changes in relative efficiency, measures by the difference 
$\left(d_{A} p_{A}-r_{A}\right)-\left(d_{B} p_{B}-r_{B}\right)$, increase (decrease) focus if they cause the difference in relative efficiency to increase (decrease).

The implications of this result for the relation between efficiency and focus in a population of firms depend both on the distribution of ability within these firms and on the distribution of ability across firms. Since any single firm may be relatively efficient or inefficient in both segments, or relatively efficient in either one, in principle one might observe both efficient and inefficient diversified firms, and focused firms with very inefficient small peripheral segments in other industries. The relation between efficiency and focus observed in a population of firms depends on the minimum level of efficiency required to operate in the industry. Thus, for example, if competitive pressure in an industry is sufficiently intense so that inefficient firms cannot operate in industry, we would never observe inefficient diversified firms.

To fix ideas, consider the special case of a population of potential conglomerate firms which are all equally efficient in industry $B\left(d_{B}=1\right.$ for all firms, say), whereas firms' abilities in industry $A$ are distributed over an interval (so that some firms have low efficiency in industry $\mathrm{A},\left(d_{A},<1\right)$, whereas other firms may have a high efficiency in industry $\mathrm{A},\left(d_{A}>\right.$ 1)). Those firms with high efficiency in industry $\mathrm{A}\left(d_{A}>1\right)$ will be focused in producing in industry $A$. They are also highly efficient, and will be large because their output in industry $A$ is large. Firms with a somewhat lower efficiency in industry $\mathrm{A}$, those with a lower $d_{A}$, will be less focused, smaller, and on average less efficient. At the point where $d_{A}=d_{B}=1$, a firm is fully diversified. Thus, for firms where $d_{A}>1$ there is positive relation between focus and efficiency. For these firms we would expect to observe a conglomerate discount.

For firms who are less efficient in industry $\mathrm{A},\left(d_{A}<1\right)$ there is a reversed relation between efficiency in industry $\mathrm{A}, d_{A}$, and focus. Firms whose $d_{A}$ is close to one would optimally choose to be almost fully diversified. Firms whose $d_{A}$ is very low will heavily focused in industry $B$. Thus, for these firms there is a negative relation between focus and efficiency. For this sub-population of firms we would expect to observe a conglomerate premium. These firms are also in general smaller than the firms that are more efficient in industry $A$.

The distribution of managerial talent and the ability to produce in multiple industries also determine optimal production when we allow the efficiency of firms in both industries to vary. If managerial talent is industry specific, all firms produce most in industries where they are relatively more efficient, so that within each firm there is a positive relation between segment size and productivity. Firms that are highly productive in one industry are likely to be less productive in the other industry. For these firms, the difference between $d_{A}$ and $d_{B}$ is likely to be large. As a result, firms with highly talented managers are focused, with 
most of their production in one industry. Firms whose managers are not as highly skilled in any one industry are less focused.

By contrast, if managerial talent is not industry specific, so that $d_{A}=d_{B}$, all firms divide their production equally between the industries. In this case, there is no relation between productivity and focus, and there are no differences in productivity across segments. Larger firms, however, are more productive than smaller firms across all segments

We illustrate these two possible outcomes for our model using two numerical examples in which we increase the number of industries to ten. In each example 25,000 potential firms each "draw" their managerial talent in each of the ten industries. We draw each ability from an Normal distribution with a mean ability of 1 and a standard deviation of .5. The output and input prices, and the cost parameters, in all industries are held constant, $(p=200$, $r=200, w=5, v=2$ ). In the first example firm ability is industry specific. Firms' ability to manage in one industry is independent of their ability in the other industries. Thus, the draws are independent and identically distributed both within firms and across firms. In the second example, there is a firm specific effect: the draws within a firm for each of the ten industries are correlated. We draw the common ability from a normal distribution with a mean equal to 0 and standard deviation equal to .25. We add this common ability to the random industry ability drawn earlier. Thus, part of firm's ability can be applied equally to all industries. In each case we determine which industries in which it is optimal for each firm to produce and also the amount of each firms' production in each industry, given the price of output and the prices of inputs. We keep track separately of firms that choose to produce in one industry only, two industries only, to firms that choose to produce in all the industries (if such firms exist). Thus, we have simulated data on one segment firms, two

segment firms etc. For all firms with a given number of segments, we rank the segments by size, and we compute the mean managerial talent $d$ for that segment.

\section{Insert Figure 1a here}

Figure 1a illustrates the case in which managerial ability is not correlated across industries in which the firm produces. The figure shows how average managerial talent varies by the number of segments a firm operates in and by segment rank. As predicted, the figure shows that within firms the main segments of conglomerates are better managed than peripheral segments. As we go across the number of segments in which a firm operates, equally ranked segments at first become more efficient, and then less efficient. The drop-off 
in efficiency occurs because it is very unlikely that any single firm is efficient in all ten industries. Thus, firms that choose to produce in many industries are likely to have mediocre ability in all of them. In this example, there are no firms in the sample that produce in all the industries. A simple OLS regression shows that firms' mean efficiency is positively and significantly related to their focus, measured by the Herfindahl index, and size.

\section{Insert Figure 1b here}

In Figure 1b we allow some firms to be more efficient than other firms in all their operations. We still see that main segments are more efficient than peripherals. However, now equally ranked segments are more productive in firms that operate in more segments. Firms that choose to operate in many segments are more efficient in general. Interestingly, a simple OLS regression shows that firms' mean efficiency is again positively (albeit less than the case with no common firm talent) and significantly related to their focus, measured by the Herfindahl index, and size.

These examples show that while the model makes predictions about the distribution of firms' production, this distribution of production across industries depends on the distri-

bution of ability. As we show below, the pattern of decreasing ability in smaller segments is consistent with our empirical findings. However, the predictions which the examples illustrate do not help differentiate the model from agency models, which predict that firms inefficiently expand into industries outside their core competence. To help differentiate the agency and the neo-classical view, we extend the model to yield predictions on how demand shocks in one industry affect the growth of a conglomerate in its other industry.

\section{B. Shocks and Growth of Conglomerate Firms}

In this section we show how the growth rates of conglomerate firms's segments respond to shocks in their own and other industries. We begin by analyzing how firms respond to shocks within the industry and then generalize the model to multiple industries. We then show how our predictions differ from those of agency models.

\section{Shocks and Growth in a Single Industry}

We first analyze the relative growth rates and the flow of assets between differing productivity over the business cycle in a single industry. Accordingly, in this subsection we assume that all firms in the industry are single-segment firms that produce only in one industry, assume that $v=0$, and we drop all industry subscripts. 
For simplicity we assume that firm talent can take one of two values. Let $H$ firms produce one unit of that industry's output per unit of capacity, so that for these firms $d=1$. $L$ firms produce only $d<1$ units of output per capacity unit. The proportion of firms that are $H$ firms is $\lambda$, and the optimal number of capacity units operated by $H$ and $L$ firms is $k^{H}$ and $k^{L}$, respectively.

To make explicit the role of demand shocks and the distribution of capacity units on firm growth, we describe the equilibrium in the market for output. The market price that the customers pay in industry for the output is determined as $p=a-b Q$, where $Q$ is the aggregate output and $b$ is a positive constant. The intercept $a$ is a positive random variable. A positive shock occurs when the realization of $a$ exceeds its expected value. A negative shock is defined analogously. We focus on the capacity flows that occur at time $t=1$, when $a$ is revealed.

Proposition 2 If the supply of total capacity is not perfectly elastic, then in industries experience a positive (negative) demand shock, highly productive firms grow (decrease) in size relative to less productive firms.

Proof

We obtain the output of high-quality firms by maximizing the firm's operating profit, $p k^{H}-r k^{H}-w\left(k^{H}\right)^{2}$. Solving for $k^{H}$, we obtain $\frac{p-r}{2 w}$ as the optimal capacity that high-quality firms operate at the given opportunity cost, $r$. We obtain the capacity at which the lowquality firms operate is similarly obtained as $k^{L}=\frac{p d-r}{2 w}$. Notice that $k^{H}>k^{L}$, so that a high quality firm uses more capacity than the low-quality firm at every price level.

If both $H$ and $L$ firms are active in the industry and the price of capacity exceeds its salvage value, the market price of the output is $p=a-b n\left(\lambda k^{H}+d(1-\lambda) k^{L}\right)$. We determine the price of capacity by equating the demand for capacity by each type of firm to the total number of capacity units available, either on the secondary market or as supplied by manufacturers, so that

$$
\alpha+\beta r=\lambda n \frac{p-r}{2 w}+(1-\lambda) n \frac{p d-r}{2 w} .
$$

The first term on the right hand side of the equation is the demand for capacity by the $\lambda n$ high-quality firms. The second term is the demand for capacity by the $(1-\lambda) n$ low-quality firms. Solving equation (1) for the opportunity cost of capacity, and taking into account salvage value, yields

$$
r=\max \left[\frac{p(\lambda+d(1-\lambda))}{n+2 \beta w}-\frac{2 w \alpha}{n+2 \beta w}, s\right]
$$


We focus on the region in which the supply of capacity is not perfectly elastic, $r>s$. Substituting the expression for the rental cost of capital (2) into the expressions for the desired capacity by high- and low-quality firms, we obtain

$$
k^{H}=\frac{\alpha}{n+2 \beta w}+\frac{(1-d)(1-\lambda) n+2 \beta w}{2 w(n+2 \beta w)} p \text { and } k^{L}=\frac{\alpha}{n+2 \beta w}-\frac{(1-d) \lambda n-2 \beta d w}{2 w(n+2 \beta w)} p .
$$

In this region, the derivative of the ratio $\left(k^{H} / k^{L}\right)$ with respect to the output price, $p$, is

$$
\frac{2(1-d)(n+2 \beta w) w K}{(2 w \alpha+(2 \beta d w-(1-d) \lambda n) p)^{2}}>0 \text {. }
$$

Thus, as $p$ increases, the ratio $k^{H} / k^{L}$ increases. Positive price shocks are associated with higher growth of high-quality firms relative to low-quality firms. Since positive shocks to $a$ at time $t=1$ translate into increases in $p$, it is straightforward, but messy, to show that the same relation obtains for the ratio $k^{H} / k^{L}$ and $a$.

Proposition 2 characterizes how the sizes of efficient and inefficient firms vary in response to demand shocks. Because firms' average costs increase with size, there is an equilibrium distribution of firm size. In equilibrium, firms will increase their capacity until the marginal value of each capacity unit is the same in each firm. The optimal distribution of capacity depends on the value of the additional output that the high-quality firms can produce with each unit of capacity. At high levels of demand, as demand increases, the value of this additional output increases, and the high-quality firms in the industry will acquire additional capacity at a higher rate than low-quality firms. ${ }^{11}$ This process continues until the increase in the value of output, which occurs when a unit of capacity is transferred from a low-quality to high-quality firm, exactly equals the net increase in the costs of supervision.

While we expect the total supply of capacity in the industry to be inelastic, it may be that when demand is very low the opportunity cost of capacity is a fixed salvage price. When demand is this low it is straightforward to modify the model to show that negative demand shocks cause low-quality firms to scrap additional capacity at a higher rate than high-quality firms. Hence, negative shocks cause high-quality firms shrink less than low-quality firms. ${ }^{12}$ Positive demand shocks cause the price of capacity to exceed the fixed salvage value. When this occurs the case described in Proposition 1 again obtains, and high-quality firms grow

\footnotetext{
${ }^{11}$ This may occur through purchases of new capacity either from the manufacturer or from low-quality firms. Although we do not investigate this issue here, the latter obtains when the productivity differences between high- and low-quality firms are sufficiently great.

${ }^{12}$ Let the salvage price be $s$. Then $k^{H}=\frac{p-s}{2 w}$ and $k^{L}=\frac{p d-s}{2 w}$. The derivative of the ratio $\left(k^{H} / k^{L}\right)$ with respect to the output price, $p$, is negative.
} 
relative to low quality firms. As a result, when demand is so low that the opportunity cost of capital equals a fixed salvage price, the behavior of firm growth rates may be more complex. Since the details of this case are not central to our empirical analysis, we do not pursue it further in this paper.

\section{Growth of Conglomerates Across Industry Segments}

We make several simplifying assumptions for tractability. The proofs below are significantly simplified if we also assume that there exist some firms, denoted by superscript ss, which are constrained to operate in one segment only. ${ }^{13}$ Their ability is normalized to one, $d_{i}=1$. The profit function of a single-segment firm that operates only in industry $i$ is,

$$
p_{i} k_{i}^{s s}-r_{i} k^{s s}-\left(w_{i}+\nu\right)\left(k_{i}^{s s}\right)^{2}
$$

where we introduce a cost of management $\nu$ which is the same in both industries and we assume, without loss of generality, that single-segment firms produce one unit of output per unit of capacity. This yields an optimal output analogous to that in the single industry case, so that $k_{i}^{s s}=\frac{p_{i}-r_{i}}{2 w_{i}+\nu}$.

We assume that of the total number of firms $n$ a fraction, $\lambda_{c}$, are conglomerates. Other firms are single-segment firms. An equal number of single-segment firms operates in both industries, so that the fraction of the $n$ firms operating only industry $i$ is $\lambda_{s s}$, where $\lambda_{s s}=$ $\left(1-\lambda_{c}\right) / 2$. Similarly, we assume that the capacity in each industry is fixed at $K_{i}$.

We also focus directly on price shocks in each industry. We do not trace out the relation between a demand shock and the subsequent price shock. ${ }^{14}$ First, we analyze how price shocks in industry $A$ on the output of a conglomerate in industry $B$.

Proposition 3 If conglomerate segments in industry $A$ are sufficiently less efficient than single-segment firms also operating in industry $A\left(d_{A}<\frac{n \lambda_{s s}}{n \lambda_{s s}+2 \beta\left(\nu+w_{j}\right)}\right)$, then a positive price shock in industry $A$ results in an increase in growth rates of segments of conglomerates that operate in industry $B$ relative to the growth rate of single-segment firms in industry $B$. If the conglomerate segments in industry $A$ are more efficient than the single-segment firms in that industry $\left(d_{A}>\frac{n \lambda_{s s}}{n \lambda_{s s}+2 \beta\left(\nu+w_{j}\right)}\right)$, then a positive price shock in industry $A$ decreases the growth rate of conglomerate segments in industry $B$ relative to the growth rate of single-segment firms.

\footnotetext{
${ }^{13}$ The simplification is possible because it enables us to contrast a conglomerate's reaction to industry shocks with that of single-segment firms in each industry. This is qualitatively similar, but expositionally much simpler, to directly contrasting the reactions of two conglomerates of different ability.

${ }^{14}$ Since the full specification introduces additional terms in the expressions below, but is not material for our arguments, we do not specify it in this section. The proof of Proposition 1 for the single-industry case shows how this can be done in the two-industry case.
} 


\section{Proof}

By substituting for $k_{i}^{c}$ and $k_{i}^{s s}$ into the industry equilibrium conditions $\alpha+\beta r_{i}=\left(\lambda_{c} k_{i}^{c}+\right.$ $\left.\lambda_{s s} k_{i}^{s s}\right) n$, where $i=A$ or $B$, we can solve for the price of capital in each industry. Substituting $r_{A}$ and $r_{B}$ into the expressions for $k_{i}^{c}$ and $k_{i}^{s s}$, we obtain

$$
\frac{\delta\left(k_{i}^{c} / k_{i}^{s s}\right)}{\delta p_{j}}=-\left[\frac{2\left(\alpha+\beta p_{i}\right) \nu\left(n \lambda_{s s}+2 \beta\left(\nu+w_{j}\right)\right)\left(\Theta_{1}+\Theta_{2}+\Theta_{3}\right)}{\left(n^{2}\left(\Theta_{4}-\Theta_{5}\right)+2 n\left(\alpha \Theta_{6}+\left(\Theta_{7}+\Theta_{8}\right) \beta\right)\right)^{2}}\right]\left(\frac{n \lambda_{s s}}{n \lambda_{s s}+2 \beta\left(\nu+w_{j}\right)}-d_{j}\right),
$$

where

$$
\begin{gathered}
\Theta_{1}=4 \beta^{2}\left(\nu+w_{i}\right)^{2}\left(\nu+w_{j}\right)\left(w_{i} w_{j}+\nu\left(w_{i}+w_{j}\right)\right. \\
\Theta_{2}=2 \beta n\left(2 \nu+w_{i}+w_{j}\right)\left(\left(1-2 \lambda_{s s}\right) \nu^{2}+\left(1-\lambda_{s s}\right)\left(w_{i} w_{j}+\nu\left(w_{i}+w_{j}\right)\right)\right. \\
\Theta_{3}=n^{2}\left(1-2 \lambda_{s s}\right) \nu^{2}+\left(1-\lambda_{s s}\right)^{2}\left(w_{i} w_{j}+\nu\left(w_{i}+w_{j}\right)\right. \\
\Theta_{4}=\left(1-2 \lambda_{s s}\right)\left(\left(1-d_{i}\right) p_{i}\left(1-\lambda_{s s}\right)\left(v+w_{j}\right)+\left(1-d_{j}\right) p_{j} \lambda_{s s} v\right) \\
\Theta_{5}=4 \beta\left(\alpha+\beta p_{i}\right)\left(v+w_{j}\right)\left(w_{i} w_{j}+\nu\left(w_{i}+w_{j}\right)\right. \\
\Theta_{6}=\left(1-2 \lambda_{s s}\right) v^{2}+\left(1-\lambda_{s s}\right) w_{i} w_{j}+v\left(w_{i}\left(1-\lambda_{s s}\right)+\left(2-3 \lambda_{s s}\right) w_{j}\right. \\
\Theta_{7}=d_{j} p_{j}\left(1-2 \lambda_{s s}\right) v\left(w_{i}+w_{j}\right)-p_{i}\left(\left(2-d_{i}\right)\left(1-2 \lambda_{s s}\right) v^{2}\right. \\
\Theta_{8}=w_{j}\left(w_{i}\left(1-\lambda_{s s}\right)+\left(1-d_{i}\right)\left(1-2 \lambda_{s s}\right) w_{j}-v\left(\left(1-\lambda_{s s}\right)+3-\left(d_{i}\left(1-2 \lambda_{s s}\right)-5 \lambda_{s s}\right) w_{B}\right.\right.
\end{gathered}
$$

The term in the square brackets in equation (9) is positive for all feasible $\lambda_{s s}\left(\lambda_{s s}<0.5\right)$. Thus, for all sufficiently low $d_{j}\left(d_{j}<\frac{n \lambda_{s s}}{n \lambda_{s s}+2 \beta\left(\nu+w_{j}\right)}\right)$ the result follows.

When a positive demand shock occurs in industry $A$, relatively efficient firms increase their market share. Conglomerates that are sufficiently inefficient lose capacity to other firms in that industry. ${ }^{15}$ This reduction in capacity reduces their control costs. As a result, they become more aggressive competitors in industry $B$, and grow relatively faster than do other firms in that industry. When conglomerates are relatively more efficient in industry $A$, a positive shock in that industry causes them to expand faster in that industry, their control costs increase, and they become relatively less aggressive competitors in industry $B$.

We also develop predictions about the role of demand shocks on the optimal size of a conglomerates operations within industries. For tractability, we only derive results for the case where the total capacity is fixed, so that $\beta \rightarrow 0$.

${ }^{15}$ Note that "sufficiently" depends on the elasticity of supply of capacity into the industry. If supply is fixed $(\beta=0)$, then it is sufficient that $d_{j}<1$. 
Differentiating equation (9) with respect to $d_{j}$ we obtain:

Corollary 1 The greater the efficiency of a conglomerate's operations in an industry, the greater the effect of price shocks in that industry on the optimal size of operations of the conglomerate in other industries.

We thus would expect that shocks in a conglomerate's main segment (which, all else being equal, has a higher relative efficiency) would produce greater effects on the industries in which it has its peripheral segments than if the opposite were true.

Note that we do not predict this pattern of growth across conglomerates business units because the conglomerate firms have an internal capital markets that are superior to those of single-industry firms. Rather, they result from the comparative advantage of conglomerates and single-segment firms over different ranges of demand.

\section{Empirical Analysis: Firm Growth over the Business Cycle}

In this section we explore our predictions on how industry demand and supply conditions influence the growth of business segments. Our null hypothesis is that the growth is explained by industry demand and returns-to-scale, as well as firm-specific productivity, and that there are no agency costs.

To examine whether industry demand and supply conditions influence segment growth, we investigate both long-run changes in industry shipments and short-run changes in aggregate industry investment. By using detailed micro-level plant data, we can control for the changing composition of firms and accurately examine growth at the segment level.

We use three approaches to testing our model. First, we calculate the productivities of conglomerates (main and peripheral industry segments) and of single-segment firms, and examine whether they accord with the patterns predicted in Proposition 2. While this test could reject our model, it does not allow us to differentiate between the model and agency models which posit that conglomerates invest in peripheral segments for noneconomic reasons.

To differentiate between our model and agency models, we examine and test the growth patterns of conglomerates and compare them to growth patterns of single-segment firms. One of our model's the key predictions is that firms invest differently across business segments based on comparative advantage and returns to scale in business segments. Specifically, we test the prediction of Proposition 3 that conglomerates will grow less in a particular segment if their other segment(s) is (are) more productive and if their other segment(s) experiences 
a larger positive demand shock. Agency models do not predict this relation. Rather, they suggest that positive shocks in other segments provide additional resources for the expansion of peripherals.

Finally, as a robustness check, we identify a subsample of "failed" conglomerates that were split up over our sample period. If market forces are important in breaking up those conglomerates that have agency problems, then the failed conglomerates will be less likely to follow optimal policies than will the complementary subsample of conglomerates that survive. Thus, by comparing the fit of our model in the two subsamples, we can check whether our regressions are detecting optimal resource allocation.

\section{A. Data}

We examine both multiple-segment conglomerate firms and single-segment firms by using an unbalanced panel for the period 1975 to 1992. To be in our sample, firms must have manufacturing operations producing products in SIC codes 2000-3999. We require firms to meet these criteria because of the unique nature of the micro-level data that we use to calculate plant-level productivity and industry-segment growth.

We use data from the Longitudinal Research Database (LRD), maintained by the Center for Economic Studies at the Bureau of the Census. ${ }^{16}$ The LRD database contains detailed plant-level data on the value of shipments produced by each plant, investments broken down by equipment and buildings, and the number of employees.

There are several advantages to this database: First, it covers both public and private firms in manufacturing industries. Second, coverage is at the plant level, and output is assigned by plants at the four-digit SIC code level. Thus, firms that produce under multiple SIC codes are not assigned to just one industry. Third, plant-level coverage means that we can track plants even as they change owners.

The LRD tracks approximately 50,000 manufacturing plants every year in the Annual Survey of Manufactures (ASM). The ASM covers all plants with more than 250 employees. Smaller plants are randomly selected every fifth year to complete a rotating five-year panel.

We confine our analysis to 1975 through 1992. We use 1975 as the starting year of our analysis because it is the first year of a five-year panel; 1992 is the last year of data available to us. We aggregate our data into firm business-segment units at the three-digit SIC code from the individual plant-level data. We exclude segments that are less than $\$ 1$ million in real value of shipments, and segments which have continuously compounded annual growth

\footnotetext{
${ }^{16}$ For a more detailed description of the Longitudinal Research Database (LRD) see McGuckin and Pascoe (1988).
} 
rates greater than $500 \%$ in absolute value.

We classify firms as single segment or multiple segment based on three-digit SIC codes. If a firm produces $97.5 \%$ of its sales or higher in one three-digit SIC code, we classify that firm as a single-segment firm and exclude the small peripheral segment. We classify all other firms are multiple-segment firms. For these firms, we also classify each segment as either a main segment or a peripheral segment. Main segments are segments whose real value of shipments (in 1982 dollars) is at least $25 \%$ of the firm's total shipments.

\section{B. Variable Selection}

In this section we describe the variables used to test our model and how we calculate the fundamental industry and segment-level variables used in our tests. Specifically, we use segment productivity, calculated industry returns-to-scale, business cycle indicators and the change in aggregate industry shipments to test the predictions of our propositions. In addition to these measures we examine how growth is related to industry segment cash flow.

\section{B1. Productivity of Business Segments}

We calculate productivity for all firm segments at the plant level. Our primary measure of performance is total factor productivity (TFP). TFP takes the actual amount of output produced for a given amount of inputs and compares it to a predicted amount of output. "Predicted output" is what the plant should have produced, given the amount of inputs it used. A plant that produces more than the predicted amount of output has a greater-thanaverage productivity. This measure is more flexible than the cash flow measure, and does not impose the restrictions of constant returns to scale and constant elasticity of scale that a "dollar in, dollar out" cash flow measure requires. ${ }^{17}$

In calculating the predicted output of each plant, we assume that for each industry there exists a production function that defines the relation between a plant's inputs and outputs. Then, for each industry we estimate this production function using an unbalanced panel with plant-level fixed effects, using all plants in the industry within our 1975 to 1992 time frame.

We assume that the plants in each industry have a translog production function. This functional form is a second-degree approximation to any arbitrary production function, and therefore takes into account interactions between inputs. To estimate predicted outputs,

\footnotetext{
${ }^{17}$ For robustness, we also explore how industry segment growth is related to segment cash flow, both of the segment in question and the cash flow of the conglomerates other segments. The results using cash flow also show strong support for our neoclassical model. These results for several of the subsequent tables are available from the authors.
} 
we take the translog production function and run a regression of log of the total value of shipments on the log of inputs, including cross-product and squared terms:

$$
\ln Q_{i t}=A+a_{i}+\sum_{j=1}^{N} a_{j} \ln L_{j i t}+\sum_{j=1}^{N} \sum_{k=j}^{N} a_{j k} \ln L_{j i t} \ln L_{k i t}
$$

where $Q_{i t}$ represents output of plant $i$ in year $t$, and $L_{j i t}$ is the quantity of input $j$ used in production for plant $i$ for time period $t$. $A$ is a technology shift parameter, assumed to be constant by industry, $a_{i}$ is a plant-firm specific fixed effect (if a plant changes owners a new fixed effect is estimated. We leave off the firm subscript for tractability), and $a_{j}=\sum_{i=1}^{N} a_{j i}$ indexes returns to scale.

Our measure of TFP at the industry segment level is the weighted average of standardized plant-level productivities, where the plant-level productivity is the residual from equation (18) plus the fixed effect, $a_{i} \cdot{ }^{18}$ We standardize plant-level TFP by dividing by the standard deviation of TFP for each industry. Thus, our comparisons of plants' TFP are not driven by differences in the dispersion of productivity within each industry.

In estimating the TFPs in our sample, we use data for over 500,000 plant years, and for approximately 50,000 plants each year. In the productivity regression for each industry, we include three different types of inputs, capital, labor, and materials, as explanatory variables. All these data exist at the plant level. However, the ASM does not state the actual quantity shipped by each plant, but shows only the value of shipments. As a result, we take the difference between actual and predicted value of shipments as our measure of TFP. We adjust for inflation by using four-digit SIC code data from the Bartelsman and Gray (1994) database. We use data from the Bureau of Economic Analysis to make depreciation adjustments at the two-digit level. To capture vintage effects of capital, we include plant age in our productivity calculations. Plant age is the first year in which the plant appeared in the database, or 1972 (the first year of the database) whichever is earlier. Kovenock and Phillips (1997) describe these inputs and the method for accounting for inflation and depreciation of capital stock in more detail.

To measure the productivity for a firm's entire business segment, we construct a weighted average of individual plant productivity, in which the weights are the plant-level value of

\footnotetext{
${ }^{18}$ In addition to this specification for plant productivity, we also estimate four other related specifications. First, we just use the average of the plant fixed effects for the firm's division as a measure of firm ability in that segment (omitting the residual). Second, we estimate the above regression at the three digit industry segment level, using a firm-industry fixed effect plus the residual as a measure of firm ability in that segment. Third, we use just the firm-industry segment fixed effect as our measure of firm ability (omitting the residual). Fourth, we estimate the fixed effect just using prior years of data for the firm-industry segment. In this last specification, we use up to five years of lagged data to estimate the fixed effect for each time period. We find similar results for all of these specifications.
} 
shipments. The variable for the productivity of the firm's other segments is the weighted average of all of the firm's other plants outside of the segment in question. Again, the weights are the plant-level value of shipments.

We also include other firm and segment-level variables in our regressions to provide additional control for unmeasured productivity differences and other factors, such as size, that can influence firm growth. We include the log of firm size and the number of plants operated by a firm at the beginning of the year. We define firm size as the total value of shipments.

\section{B2. Industry Variables: Returns to Scale, Industry Shipments and Business-Cycle Classifications}

We focus on shipment growth as the value of capital and of allocating resources to growth in an industry depends on industry growth. Similarly, industry returns-to-scale influence the value of allocating resources to a specific industry. We calculate several different measures of industry demand and supply conditions. Our central variables are industry-level returnto-scale, the yearly and long-run changes in industry shipments, and capacity utilization.

We calculate industry returns-to-scale, $\lambda$, by estimating a system of equations derived by assuming cost minimization for a given production function. The system consists of a translog production function and additional input demand equations. We estimate the translog production function simultaneously with input demand equations, equating input factor shares to the first-order conditions from the production function and imposing homogeneity of degree $\lambda$. In estimating our returns-to-scale variable, we use an unbalanced panel and aggregate all the data up to the firm three-digit SIC code. We estimate the equations used to calculate returns-to-scale using both the standard fixed effects estimator and a five-year panel difference estimator as suggested by Griliches and Hausman (1986). ${ }^{19}$

For industry shipments, we use the Bartelsman and Gray (1994) database at the threedigit SIC code level. We use industry shipments and investment data to investigate if longrun changes in an industry affect the relative growth of single-segment and conglomerate firms.

To determine whether the level of industry demand alters the relation between the ex-

\footnotetext{
${ }^{19}$ Griliches and Hausman show that measurement error problems with capital stock may cause estimates of returns-to-scale to be biased downward. We thus estimate returns-to-scale using five year differenced data, instrumented with a lagged difference. The average returns-to-scale at the three-digit level rises to .94 from .89. However, this difference does not affect the results of our regressions explaining firm growth across business segments, most probably because these results rely on the differences in returns-to-scale across industries. A histogram of our returns-to-scale estimates for three-digit industries is available from the authors.
} 
planatory variables and segment growth, we also classify years as recession or expansion years. We determine recession and expansion years by using aggregate and aggregate-detrended industrial production. We define detrended industrial production as the actual less predicted industrial production, where we calculate predicted industrial production from a regression of industrial production on a time trend. Recession years are years in which both real and detrended industrial production decline relative to the previous year. We classify years as expansion years when both real and detrended industrial production increase relative to the previous year.

This procedure gives us similar results as the NBER recession dating procedure, which NBER does quarterly. It also allows us to classify a year such as 1980 , which, according to NBER, had a recession of less than six months. Using this procedure, we classify 19811982 and 1990-1991 as recession years and 1976-1978 and 1984-1988 as expansion years. Given that actual and detrended industrial production did not move in the same direction, 1979-1980, 1983, 1989, 1992 are indeterminate years

We also divide our sample of industries into quartiles according to level of demand. We classify industries into "demand" or change-in-shipment quartiles by constructing an index of long-run changes in real industry shipments over a ten-year period following Maksimovic and Phillips (1998).

We then aggregate for each firms the plants it owns in each industry into industry segments, and examine the relative number and the productivity of industry segments of multiple- and single-segment firms in each quartile. Using this procedure, we examine whether multiple- and single-segment firms have differential growth rates just because they are in industries that experience different long-run growth rates.

\section{Results}

\section{A. Sample Summary Characteristics}

Table I presents summary statistics for the firms in our dataset. We break out the statistics by single- and multiple-segment firms. We present both real-growth rates and the proportion of total real-dollar value of shipments by industry segments. We calculate real-growth rates by using individual plant-level shipments deflated by four-digit SIC code deflators from the NBER productivity database.

For multiple-segment firms, we subclassify their segments as either main or peripheral segments. We classify a segment as a main segment if it represents at least $25 \%$ of a firm's total value of shipments. (Note that a firm can have multiple "main" segments.) We also present real-growth rates by recession and expansion years for the segments that are in 
the top $50 \%$ of the distribution of total factor productivity. We determine recession and expansion years are determined as described in the previous section.

\section{Insert Table I here}

Table I shows that from 1980 to 1990, the proportion of output produced by singlesegment firms in the U.S. manufacturing sector increased by five percentage points. This increase occurred because of a substantial increase in the number of new single-segment firms and because multiple-segment firms decreased production in their peripheral segments. We also see that multiple-segment firms' main divisions show almost a zero growth rate in recessions, and that single-segment firms and peripheral segments of multiple-segment firms register negative growth. Finally, the table shows that for both conglomerates and singleindustry firms, efficient firms grow at substantially higher rates.

In Figure 1 we examine how the efficiency of conglomerates' segments varies with the size ranking of the segment within the conglomerate, and with the total number of segments. Figure 1 shows that there is a strong negative relation between the segment's rank and efficiency. This is consistent with the neo-classical hypothesis that conglomerates focus on the segment on which they have a comparative advantage. This within conglomerate drop-off in productivity in smaller segments suggests that managerial talent has an industry-specific component.

\section{Insert Figure 2 here}

Figure 2 also shows how the productivity of segments that are equally ranked by size within the conglomerate varies as the number of segments increases. Holding the withinconglomerate rank of a segment constant, its productivity increases as the total number of segments increases. Thus, for example, the mean efficiency of the largest segment of a twosegment conglomerate is lower than its industry average, whereas the mean efficiency of the largest segment of a conglomerate with more than ten segments or more is higher. This is consistent with the hypothesis that there are a number of large efficient conglomerates whose managerial talent is portable across industries. A larger number of conglomerates operate in a small number of segments, and are of less than average efficiency, even in their best 
industry. Again, this relation is consistent with the neo-classical model. It is also consistent with the result of Lang and Stulz (1994) that the conglomerate discount is most prevalent in two-segment firms.

The comparison of equally-ranked segments for conglomerates of different sizes suggests that firms may become conglomerates for different reasons. Some firms may have above average managerial talent that is partially transferable across industries, and may exploit it optimally expanding into several industries. Other firms may have less than average managerial ability in their main industry, and may move into a second industry because they have attained their optimal size in their main segment. We would expect the former to be highly valued by the stock market and the latter to have a low valuation. As a result, it is difficult to interpret conglomerate discounts as evidence of agency problems. Instead, conglomerate discounts and premia may reflect the underlying distribution of managerial talent and the extent to which it is industry specific.

\section{B. Growth and Efficiency over the Business Cycle}

We first show how the average real growth and productivity of segments of single-segment and conglomerate firms can vary by size. Since our model predicts a different relation between productivity, size, and growth in response to positive and negative industry shocks, we report the results separately for expansion and recession years in the U.S. economy. These results appear in Tables II and III, respectively. In these tables, we define the size of each segment as the ratio of the size of the segment to the size of the median segment in the same industry, both measured at the beginning of the year.

\section{Insert Table II here}

Table II examines three predictions of our model. First, we test whether single-segment firms are more efficient than conglomerate firms. Second, we test whether the main divisions of conglomerate firms are more efficient than peripheral divisions. Third, we examine how the relation between growth and productivity during expansions and recessions differs for conglomerate firms' main and peripheral divisions.

Table II shows that single-segment firms have significantly higher productivity than conglomerate firms in four of the table's five size classes. The final column shows that conglomerate main divisions are significantly more productive than peripheral divisions for all size classes. 
The third finding in Table II is that there is a strong positive association between growth and productivity in expansions, and that size is very important to this relation. Firms that are large at the beginning of the year tend to be more efficient, but grow at a slower rate than smaller firms. This finding seems to indicate that smaller firms grow much faster than large, efficient ones. However, small firms tend to have a wider range in efficiency. If we look at the most efficient $50 \%$ of firms for each size class, we find that growth rates do increase with efficiency. Finally, the table shows that conglomerates grow their efficient main divisions at a much faster rate than their inefficient peripheral divisions.

These results show that a relation exists between productivity and segment type, and that it is consistent with our model. As a result of this relation, the main and peripheral segments of conglomerates should not be investing similarly when there is a positive industry shock to demand. We explore this prediction in the regressions below.

\section{Insert Table III here}

Table III shows how recession affects the three segment types. First, for each size class, firm growth increases with efficiency for single-segment firms and for divisions of conglomerates. Second, conglomerate firms cut growth much more in their peripheral divisions than in their main divisions. Sales in their peripheral divisions decrease sharply, although for some size classes, the main divisions actually grow in real terms in the recession years. Finally, single-segment firms are more affected by recessions than main divisions of conglomerate firms, but nevertheless show higher growth rates than do the peripheral divisions of the conglomerate firms.

We also explore the average annual growth rates for single-segment and multiple-segment firms during recession and expansion years for segments of different levels of efficiency. Our model predicts that the difference between the growth rates of efficient and inefficient firms should be lower during recessions than expansions. Thus, we compare the industry-adjusted annual growth rates of the most productive quartile of firm segments with the quartile of least productive segments. We find that the difference in annual growth rates between the most- and least-productive quartiles of industry segments was two to 2.5 percentage points higher in expansion years than in recession years.

Specifically, the difference in the growth rates between the main divisions of conglomerate

firms in the highest productivity quartile and the main divisions in the lowest productivity 
quartile is two percentage points more during expansion years than during recession years. For single-segment firms and peripheral segments, the difference in growth rates between segments in the highest and lowest productivity quartiles is 2.5 percentage points higher in expansions than in recessions.

Before we examine the regression results, we can draw three conclusions. First, during both expansions and recessions, growth increases with efficiency for nearly all size-based classifications. Second, efficient firms grow relatively faster in expansion years than during recession years. This finding is consistent with our model, where the difference in firm responses to shocks is greatest at high levels of demand. Third, peripheral segments experience the worst real growth declines in recession years. This may imply that conglomerate firms either use their peripheral divisions to subsidize main divisions. Alternatively, conglomerates could be cutting back on inefficient divisions in response to large negative industry shocks, as predicted by the neoclassical model. We investigate these findings further in our regressions in the next section.

We also examined whether the disparity in the performance of conglomerate firms' main divisions and their peripheral divisions can be explained by industry differences. It could be that peripheral divisions are in low-growth industries and main divisions are in high-growth industries. To control for industry growth, we examined high and low growth quartiles of all industries based on a 12-year real-growth rate of shipments described in the earlier section. Results available from the authors show that separate long-run analyses of high- and lowgrowth industries does not substantively change the previous results. The sharp differences between the main and peripheral divisions of conglomerates remain. Peripheral divisions grow at a much slower rate and are less efficient both in high- and low-growth industries.

\section{Growth and Relative Productivity with Industry Shocks}

Table IV examines the effect of productivity and industry fundamentals on the realgrowth rates of conglomerate and single-segment firms in multivariate regressions. We measure the dependent variable, industry-adjusted segment growth, in real 1982 dollars, subtracting out the industry average. Productivity and industry-segment size are industry adjusted and represent deviations from industry averages.

To capture industry fundamentals we include both industry returns to scale $(\lambda)$ and the annual change in real shipments. For each segment, we control for the segment's productivity (TFP), the total the number of plants owned by the firm to which the segment belongs, and the log of firm size. The last two variables are lagged to represent values at the beginning of the year. Thus, for every segment, the regressions control for both the segment's own 
productivity, and for firm and industry characteristics.

Our model predicts that the growth of a segment depends on the interaction between the segment's productivity and the sign of the demand shock in the industry. For positive (negative) shocks, growth is predicted to vary positively (negatively) with productivity. The magnitude of the effect depends on the returns-to-scale in the industry. To test for this interaction, we include a variable that interacts the change in industry demand with the segment's productivity.

Our model also predicts that the growth of a conglomerate firm's segment depends on the relative productivity demand conditions facing the firm's other segments. Specifically, a segment of a given productivity will grow faster (slower) if the firm's other, more-productive segments receive negative (positive) shocks and other, less-productive segments receive positive (negative) shocks.

In our regressions, we use three variables to measure how the growth of a conglomerate firm's segment is affected by the firm's other segments. First, we measure the productivity of the other segments by weighing the TFP of each segment by its sales. Second, we test for the interaction between the segment's shock and the shocks in other segments by interacting the segment's relative industry demand with the other segments' weighted productivity. We measure relative industry demand by a variable that equals one (zero, minus one) when the segment's change in shipments at the industry level is greater (equal, less) than that of the firm's median segment. Our model predicts that this variable will have a negative coefficient. Third, to capture the returns-to-scale in the other segments, we also weigh the returns-to-scale in each of the industries in which the conglomerate operates by the sales in that industry. Our model predicts that firms grow less in a particular segment if other segments have higher industry returns-to-scale.

We estimate the regression for all firms, both single- and multiple-segment firms, and for single- and multiple-segment firms separately. For the regression for all firms, the multiplesegment variables are equal to zero if the firm only has one industry segment. We estimate the regressions using unbalanced panel techniques and allow for correlated residuals within panel units. Standard errors are corrected for heteroskedasticity. ${ }^{20}$

\section{Insert Table IV here}

\footnotetext{
${ }^{20}$ We also estimate these regression equations using standard fixed effects and find similar results. Timeinvariant variables, such as returns-to-scale, are omitted from this specification. In addition, we estimate this specification using productivity measured using just a fixed effect at the industry-segment level. Again, we find qualitatively similar results. These tables are available from the authors.
} 
The regression results in Table IV show that industry returns-to-scale and the change in industry shipments are both highly significant and positively related to real firm growth. Multiple-segment firms are more sensitive to industry returns-to-scale and to the change in aggregate industry shipments than are single-segment firms. This suggests that conglomerates take into account the prospects of their other divisions. Both single- and multiplesegment firms' growth rates are significantly and positively related to segment productivity. The sensitivity is actually significantly greater for multiple-segment firms than it is for singlesegment firms. This is in contrast to the prediction of agency models in which conglomerates dissipate resources. Firm size and the number of plants are both negatively related to firm growth, which suggests that there are additional decreasing returns to scale beyond those measured by the industry returns-to-scale parameter.

The evidence on the interaction effects is consistent with the predictions of our model. The own-segment interaction variable, real change in the segment's shipments times productivity, is positive and significant. Firms increase more in size when they receive a positive shock to a division in which they are efficient.

When we look at the interaction effects for conglomerate firms, we find evidence that the division's growth rate is affected by the prospects of the firm's other divisions. As predicted by our model, the segment's growth rate is negatively related to the interaction variable for a conglomerate's other divisions, relative demand times the other segments' productivity. Thus, segment growth is less when the other segments are more efficient and receive a positive demand shock. Finally, the negative coefficient on other segments' TFP shows that a segment grows at a lower rate when the other segments are more efficient. ${ }^{21}$

These results show that firms grow faster in segments that are more efficient and that firms take into account the prospects of their other segments in a way that is consistent with the neoclassical maximizing firms in our model. While we do not have a precise benchmark for the optimal level of growth, the fact that conglomerate industry-adjusted growth rates

\footnotetext{
${ }^{21}$ As earlier noted, for comparability to previous literature, we also explore how industry segment growth is related to segment cash flow, both of the segment in question and the cash flow of the conglomerate's other segments. We find that the results using cash flow also show strong support for our neoclassical model: a segment's growth rate is positively related to its own cashflow and is negatively related to other segments cash flow for peripheral divisions. We also find a strong negative relationship to relative growth interacted with the firm's other segments' cash flow. There are several explanations for the differences between our results and prior work. First, all of our data is at the plant-level and is then aggregated up to the industry-segment level. Thus, we can more accurately assess segment cash flows and segment prospects. Second, we include variables that directly measure the industry conditions. Finally, our sample of firms is more comprehensive than previous studies.
} 
are highly sensitive to segment productivity and to industry returns-to-scale is consistent with conglomerates making efficient resource allocation decisions. ${ }^{22}$

\section{Growth of Conglomerates' Main and Peripheral Divisions}

Table $\mathrm{V}$ estimates the same regressions, but breaks the conglomerate multiple-segment firms into their main and peripheral divisions. In the last column, we test for significant differences in coefficients between main and peripheral divisions of conglomerates.

\section{Insert Table V here}

The results in Table $\mathrm{V}$ show that main and peripheral divisions' growth rates have similar sensitivity to industry returns to scale and industry shipments. There are significant differences in the sensitivity of the segment growth to productivity. The peripheral segments are actually more sensitive to productivity. Conglomerate firms also grow their peripheral divisions less when they have other segments that are highly productive. Consistent with the neoclassical model, the interaction variable, relative demand times other segments' TFP, is significantly negative for both main and peripheral segments. These findings are consistent with efficient resource allocation to peripheral segments.

Overall, the results in Tables IV and V suggest that conglomerate firms take into account the prospects of other divisions when allocating resources that help the firm grow. We find that the growth rate of both main and peripheral segments responds positively to segment productivity and industry variables that capture the fundamental prospects for that division. Especially in peripheral segments, segment growth is dependent on productivity in both the division and the other divisions. These findings do not support the conclusion that conglomerate firms inefficiently allocate resources to peripheral divisions.

Table VI examines the economic significance of our regression results using the estimated coefficients from the regressions in Tables IV and V. We calculate predicted real-growth rates of conglomerate and single-segment firms as productivity and change in shipments varies from the 25 th to the 75 th percentiles. In computing these predicted growth rates, we hold all variables at their sample medians except productivity and change in industry shipments.

\footnotetext{
${ }^{22}$ It is also consistent with an equal level of agency problems for both conglomerate and single-segment firms if the optimal sensitivity is higher for firms.
} 


\section{Insert Table VI here}

The results in Table VI show that both single-segment and conglomerate firms are very sensitive to both productivity and the change in industry shipments. Comparing the results for single-segment firms and conglomerate firms' main divisions, we find that there is little economic difference in the predicted growth rates. There is an even smaller difference when we predict growth rates holding constant productivity across regressions. When we use productivity values for the median main segment of a conglomerate to estimate the predicted growth rate of single-segment firms, we obtain a predicted annual growth rate of $10.4 \%$ compared with $10.14 \%$ for a main segment of a conglomerate firm. This result confirms that most of the difference in observed growth rates between conglomerates and single-segment firms is driven by productivity differences.

Panel B of Table VI shows that both single-segment and conglomerate firms are highly sensitive to our measure of demand shocks, changes in industry shipments. Peripheral segments of conglomerate firms actually have predicted growth rates that are negative at the 25 th percentile of change in shipments. This finding reinforces the earlier summary statistics, which show that in recessions conglomerate firms sharply cut the growth of unproductive peripheral divisions. There are substantial differences between predicted growth rates for main and peripheral segments, even when we use the data from the conglomerates' main divisions. This implies that differences in observed growth rates between main and peripheral segments are driven by differences in how the these segments grow when their productivities are equal, not just by productivity differences. The lower growth rates of peripheral divisions and the high sensitivity to productivity shows that conglomerate firms do not insulate their unproductive peripheral divisions from economic fundamentals.

\section{E. Main and Peripheral Divisions in Recession Years}

Table VII examines the behavior of conglomerate firms' main and peripheral divisions in recession years. In the last column, we test for significant differences in coefficients between these divisions.

\section{Insert Table VII here}

The results in Table VII show that peripheral divisions' growth rates are sensitive to the productivity and fundamental industry factors. Especially interesting is the fact that the 
interaction of productivity with industry shipments is actually more significant for peripheral firms than it is for main divisions. Our findings reinforce the conclusion that there is no evidence that conglomerate firms insulate their peripheral divisions from recessions.

To examine further whether peripheral firms gain additional insulation from being part of conglomerate firms, we split peripheral segments into two groups based on the sensitivity of the industry of conglomerates' main divisions to recessions. In order to measure the industry's sensitivity to recessions, we run a regression of the change in industry shipments on the change in aggregate industrial production. We rank industries by their " $\beta$ ", or their coefficient on the change in industrial production. Columns 1 and 2 present regressions for the peripheral divisions whose parents are in industries with greater than, and lower than, respectively, the median sensitivity to changes in industry shipments in recession years.

\section{Insert Table VIII here}

Table VIII shows that there are similar effects for peripheral divisions no matter what the sensitivity of their parents' main division(s) may have to recession. Only two variables, lagged size and change in shipments interacted with productivity, differ significantly across parent types. The higher significance of the interaction variable, change in shipments times productivity, provides evidence that peripherals are statistically better off with a parent company that is not exposed to the recession. However, none of the multiple-segment variables are significantly different. ${ }^{23}$

\section{Insert Table IX here}

Table IX examines the economic significance of the results in Table VIII. It shows that there is little economic difference between main and peripheral segments' responses to recessions. Thus, the observed differences in growth during recessions are attributable to differences in productivity of main and peripheral segments. However, when we classify peripherals by the exposure of their parents corporation's main segment(s) to the recession, then there is some evidence that when the parent's main segment(s) is more exposed to

\footnotetext{
${ }^{23}$ Note that the interaction variable, relative demand times TFP, has a different interpretation in this regression because we select the observations according to the magnitude of the shock in the main division(s).
} 
recession, peripherals shrink more. We then estimate the effect on growth for the peripheral division, using the productivity data from the conglomerate's main division. Conducting this experiment, we find that the economic magnitude of the effect of having a more-exposed parent is economically much less important than is the difference between main and peripheral segments.

\section{F. Robustness Tests}

The preceding tables examine resource allocation, taking the organizational form of firms as given. We now identify conglomerates which become single-segment firms. We test whether the relation between growth and efficiency for this set of firms differs from that in surviving conglomerates.

\section{F.1 Conglomerates which become Single-Segment Firms}

\section{Insert Table X here}

The results in Table $\mathrm{X}$ show that the conglomerate firms that are broken up into singlesegment firms do not respond as our model predicts to the multiple-segment variables. We note that there is an insignificant interaction of relative demand and other segments' weighted TFP for conglomerates that are broken up, but as our model predicts there is a negative, significant interaction for conglomerates which are not broken up. In addition, we find no effect for other segments' weighted TFP for the conglomerates that are broken up, but a negative, significant effect for the conglomerates that are not broken up. This evidence suggests that there is a subset of conglomerates that behave inefficiently, perhaps as a result of agency problems, and are therefore broken up.

Thus, we do find some evidence consistent with agency problems in conglomerate firms. However, even for these firms, we find no evidence that conglomerates significantly subsidize the growth of inefficient divisions. In addition, the signs of the coefficients of industry variables and productivity for the subsample of conglomerates that survive are consistent with optimal behavior. The results suggest that over our sample period, surviving conglomerates, which comprise the majority, grow efficiently across business segments.

\section{F.2 Industry Cash Flow}

Previous studies, most widely cited of which is Jensen (1986), identify cash flow as an important determinant of agency costs. Conglomerates can misallocate resources from industries with high cash flow to segments in industries that do not have profitable investment opportunities. If such effects were important, we would expect a positive relation between 
segment growth rates and cash flow levels, and increases in other segments. Such a relation is empirically supported by Lamont (1997), who finds that when oil companies receive a favorable price shock, their peripheral divisions in other industries invest more than do their industry competitors. In contrast, in a neoclassical model there is no causal relation between other segments' cash flows and segment growth. However, to the extent that high cash flows in other industry's segment signal future growth opportunities in those segments, our model would predict a negative relation between a segment's growth and industry cash flows when these are interacted with their relative productivity. ${ }^{24}$

To test for the effect of industry cash flow on our sample's growth of segments, in Table XI we examine the effect of the level and change in an industry's cash flow on the growth of that and other segments. We control for the productivity of each segment and for other fundamental industry parameters.

\section{Insert Table XI here}

The results in Table XI show that firms do not grow industry segments faster when the other segments have higher industry cash flow. In fact, for the conglomerates that are not broken up, there is a negative significant effect of other segment's industry cash flow on segment growth. In particular, a segment grows more slowly when cash flows are high in other segments. This result is consistent with our model of optimal firm growth. For conglomerates that are broken up, we do not find evidence, either negative or positive, that other segments' industry cash flow influences segment growth.

An alternative indicator of how efficiently conglomerates allocate investment is how they respond to investment prospects across industries in which they operate. We use the usual measure of industry prospects using the weighted average Tobin's $q$ of single-segment firms. Note that in our context this variable does not proxy for individual segment productivity but rather for the industry demand prospects. For conglomerate firms, our model predicts that the sign will be negative when industry prospects are interacted with the other divisions' segment-level relative productivity. There are some potential problems with interpreting results with $q$ given that in our model single-segment firms have different valuations and are not representative of the entire industry demand prospects. Therefore, using single-segment Tobin's $q$ may not proxy for the prospects of conglomerates. One other problem arose. In

\footnotetext{
${ }^{24}$ We disuss the results of using firm-specific segment cashflow in an earlier section and also in footnote 22. Maksimovic and Phillips (1998) show that industry cash flow is a proxy for long-term growth opportunities.
} 
many industries COMPUSTAT does not have data for a sufficient number of single-segment firms (our requirement was a minimum of four firms) to construct a benchmark for many of three-digit SIC codes in our data.

For the subset of data with sufficient competitors, the results of the estimation for conglomerate firms were similar to our earlier results. Given space considerations, we do not report these results. We find a negative relation between a segment's growth and other segments' weighted Tobin's $q$ interacted with our segment-level efficiency variable.

\section{Conclusions}

Our paper explores how fundamental industry conditions and productivity influence segment growth for both single industry and multiple-segment conglomerate firms. We test hypotheses derived from a neoclassical model of firm activity in multiple markets with decreasing returns to scale from managerial ability. The model yields predictions about firm-size distributions of focused single-industry and multiple-segment firms as a function of firms' comparative advantage and industry demand shocks.

We find that conglomerate firms are less productive than are single-segment firms of a similar size. This difference is mainly driven by smaller peripheral divisions of the conglomerate, which show significantly lower productivity than do main segments. This evidence supports the hypothesis that firms invest in industries in which they have a comparative advantage. This is consistent with optimal resource allocation decisions by conglomerates and also with the conglomerate discount documented by Lang and Stulz (1994) and Berger and Ofek (1995). The evidence is consistent with conglomerates having a discount because of lower efficiency, not necessarily because of agency problems. Less-efficient firms can exist in equilibrium because of industry decreasing returns-to-scale.

Examining growth of firm segments, we find that the growth of productive and unproductive firm segments (both for single-segment firms and conglomerate firms) is consistent with the model of efficient growth across business segments. Segment growth is strongly related to fundamental industry factors and individual segment productivity. In particular, peripheral divisions' growth rates are highly sensitive to productivity. Conglomerate firms grow less in a particular segment if their other segment(s) is more productive and if their other segment(s) experiences a larger positive demand shock. Firms also grow less if their other industry exhibits higher returns-to-scale. In recessions, conglomerates tend to

cut back on their less-productive peripheral segments. The differential pattern of efficiency and conglomerate growth across conglomerates' business segments, as well as a conglomerate discount, are consistent with a neoclassical model.

Our evidence is not consistent with conglomerates expanding inefficient divisions or 
protecting them from recessions by using resources from other divisions. Instead, peripheral segments are often marginal divisions whose growth declines when they have negative productivity. Our finding of high sensitivity of peripheral divisions to productivity is also consistent with the predictions of Stein (1997) in which conglomerates have an ability to allocate resources across divisions. These results hold both at the three-digit SIC code level reported in this paper and also at the two- and four-digit levels (not reported).

We do find some evidence that is consistent with some conglomerates having agency problems. We identify a subset of conglomerate firms whose growth decisions are, a priori, less likely to be consistent with our model of optimizing behavior. This subset comprises of conglomerates that were broken up during the 1980s. We find that the growth of these broken-up conglomerates is not consistent with our model of optimal growth. However, even for these firms, we find no evidence that conglomerates significantly subsidize the growth of inefficient divisions. The majority of conglomerate firms exhibit growth across business segments that is consistent with optimal behavior.

One major issue remains: We find that peripheral units of conglomerates are less productive than the main units, but that there is little evidence that peripheral growth is inefficient. This pattern is consistent with our neoclassical model of firms' comparative advantage. However, this finding of negative relative productivity of conglomerates' peripheral divisions is also consistent with conglomerates having lower fixed costs of entry and lower costs of evaluating new ventures than do single-segment firms. In future research, we expect to identify in more detail how the growth, entry, and exit decisions of conglomerates' peripheral divisions differ from their industry competitors. 


\section{REFERENCES}

Bartelsman. Eric J. and Wayne Gray, 1994, The NBER Manufacturing Productivity Database.

Berger, Philip G. and Eli Ofek, 1995, Diversification's effect on firm value, Journal of Financial Economics 37, 39-65.

Berger, Philip G. and Eli Ofek, 1997, Causes and Effects of Corporate Refocusing Programs, Journal of Finance.

Brock, William A. and David S. Evans, 1986, The Economics of Small Business: Their Role and Regulation in the U.S. Economy (Holmes and Meier, New York, NY).

Cabellero, Ricardo J., Eduardo M.R.A. Engel, and John C. Haltiwanger, 1995, Plant level adjustment and aggregate investment dynamics," Working paper, University of Maryland.

Caves, Richard E. and David R. Barton, 1991, Efficiency in U.S. Manufacturing (MIT Press, Cambridge, MA).

Coase, Ronald, 1937, The nature of the firm, Economica 4, 386-405

Comment, Robert and Greg A. Jarrell, 1995, Corporate Focus and Stock Returns, Journal of Financial Economics 37 67-87.

Denis, David J. and Bharathram Thothadri, 1998, Internal Capital Markets, Growth Opportunities, and the Valuation Effects of Corporate Diversification, working paper Purdue University.

Evans, David S., 1987, Tests of Alternative Theories of Firm Growth, Journal of Political Economy, 95 657-74.

Fluck, Zsuzsanna, and Anthony Lynch, 1996, Why do firms merge and then divest: A theory of financial synergy, working paper, New York University.

Gertner, Robert H., David S. Scharfstein, Jeremy Stein, 1994, Internal versus External Capital Markets, Quarterly Journal of Economics, 109(4), 1211-30.

Griliches, Zvi and Jerry A. Hausman, 1986, Errors in Variables in Panel Data, Journal of Econometrics, 31 93-118.

Hadlock, Charles, Michael Ryngaert and Shawn Thomas, 1998, Corporate Structure and Equity Offerings: Are There Benefits to Diversification?, mimeo.

Hall, Bronwyn H., 1987, The Relationship between Firm Size and Firm Growth in the U.S. Manufacturing Sector, Journal of Industrial Economics, 35 583-606.

Hubbard, R. Glenn, and Darius Palia, 1998, A Re-Examination of the Conglomerate Merger Wave in the 1960s: An Internal Capital Market View," forthcoming Journal of Finance.

Jensen, Michael C., 1986, Agency costs of free cash flow, corporate finance, and takeovers, American Economic Review 76, 323-329.

John, K. and E. Ofek, 1995, Asset Sales and the Increase in Focus, Journal of Financial Economics 37, 105-126. 
Kovenock, Daniel, and Gordon Phillips,1997, Capital structure and product market behavior: An examination of plant exit and investment behavior, Review of Financial Studies 10, 767-804.

Lamont, Owen, 1997, Cash Flow and Investment: Evidence from Internal Capital Markets, Journal of Finance, 52, 83-109.

Lang, Larry, Annette Poulsen and Rene Stulz, 1995, Asset Sales, Firm Performance, and the Agency Costs of Managerial Discretion, Journal of Financial Economics 37, 3-38.

Lichtenberg, F., 1992, Industrial De-diversification and Its Consequences for Productivity, Journal of Economic Behavior and Organization; 18(3), 427-38.

Lucas, Robert, 1978, On the size distribution of business firms, Bell Journal of Economics 9, 508-23.

McGuckin, Robert H. and Sang V. Nguyen, 1995, On Productivity and Plant Ownership Change: New Evidence from the LRD, RAND Journal of Economics.

McGuckin, Robert, Sang Nguyen and Arnold Reznek, 1995, The Impact of Ownership Change on Employment, Wages, and Labor Productivity, Center for Economic Studies working paper, \#95-8.

McGuckin, Robert H., and George Pascoe, 1988, The longitudinal research database: status and research possibilities, Survey of Current Business. 68, 30-37.

Maksimovic, Vojislav, and Gordon Phillips, 1997, Asset Efficiency and Reallocation Decisions of Bankrupt Firms, forthcoming Journal of Finance

Maksimovic, Vojislav, and Josef Zechner, 1991, Debt, agency costs, and industry equilibrium, Journal of Finance 46, 1619-43.

Matsusaka, John G. and Vikram Nanda, 1996, Internal Capital Markets and Corporate Refocusing, Working paper, University of Southern California.

Morck, Randall, Shleifer, Andrei and Robert W. Vishny, 1989, Alternative mechanisms for corporate control, American Economic Review 79, 842-52.

Peters, Thomas and Robert Waterman, Jr, 1982, In Search of Excellence: Lessons from America's Best-Run Companies, Warner Books, New York.

Rajan, Raghuram G., Henri Servaes and Luigi Zingales, 1997, The Cost of Diversity: The Diversification Discount and Inefficient Investment, working paper.

Ravenscraft, David and F. M. Scherer, 1987, Mergers, Sell-Offs, and Economic Efficiency. Brookings Institution, Washington.

Scharfstein, David S., 1997, The Dark Side of Internal Capital Markets II, mimeo, MIT.

Scharfstein, David S. and Jeremy Stein, 1997, The Dark Side of Internal Capital Markets: Divisional Rent Seeking and Inefficient Investments, mimeo, MIT.

Schmalensee, Richard L., 1985, Do Markets Differ Much? American Economic Review, 75, 341-351.

Shin, H. and Rene Stulz, 1997, Are Internal Capital Markets Efficient?" mimeo, Ohio State University. 
Shleifer, Andrei, and Robert W. Vishny, 1992, Liquidation values and debt capacity: A market equilibrium approach, Journal of Finance 47, 1343-1365.

Stein, Jeremy, 1997, Internal Capital Markets and the Competition for Corporate Resources, Journal of Finance 52, 111-33.

Whited, Toni, 1998, Is Inefficient Investment the Cause of the Conglomerate Discount? mimeo, University of Maryland. 


\section{Ability by Segment}

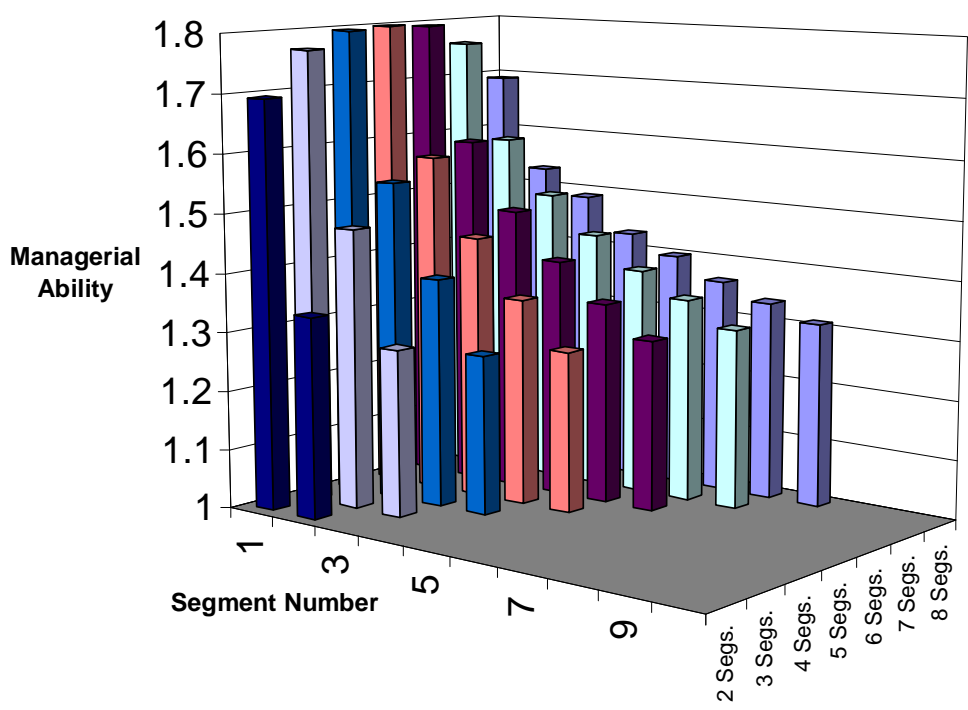

Figure 1a

Model with No Common Managerial Ability Across Industries

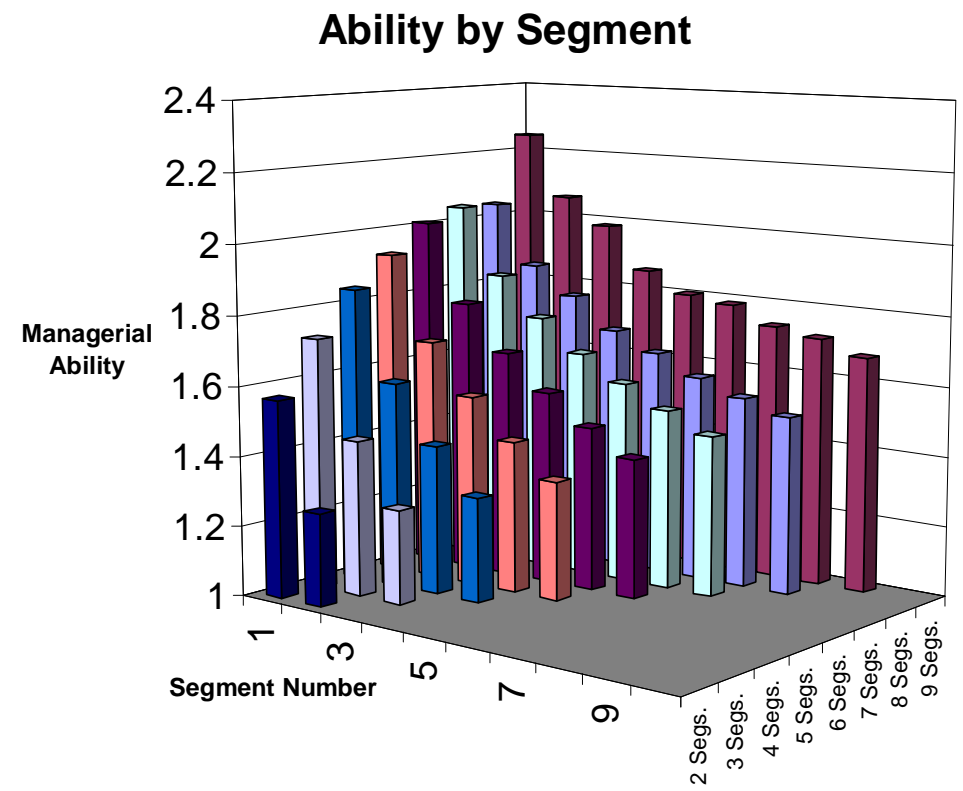

Figure 1b

Simulation of Model with Managerial Ability Applicable Across Industries 


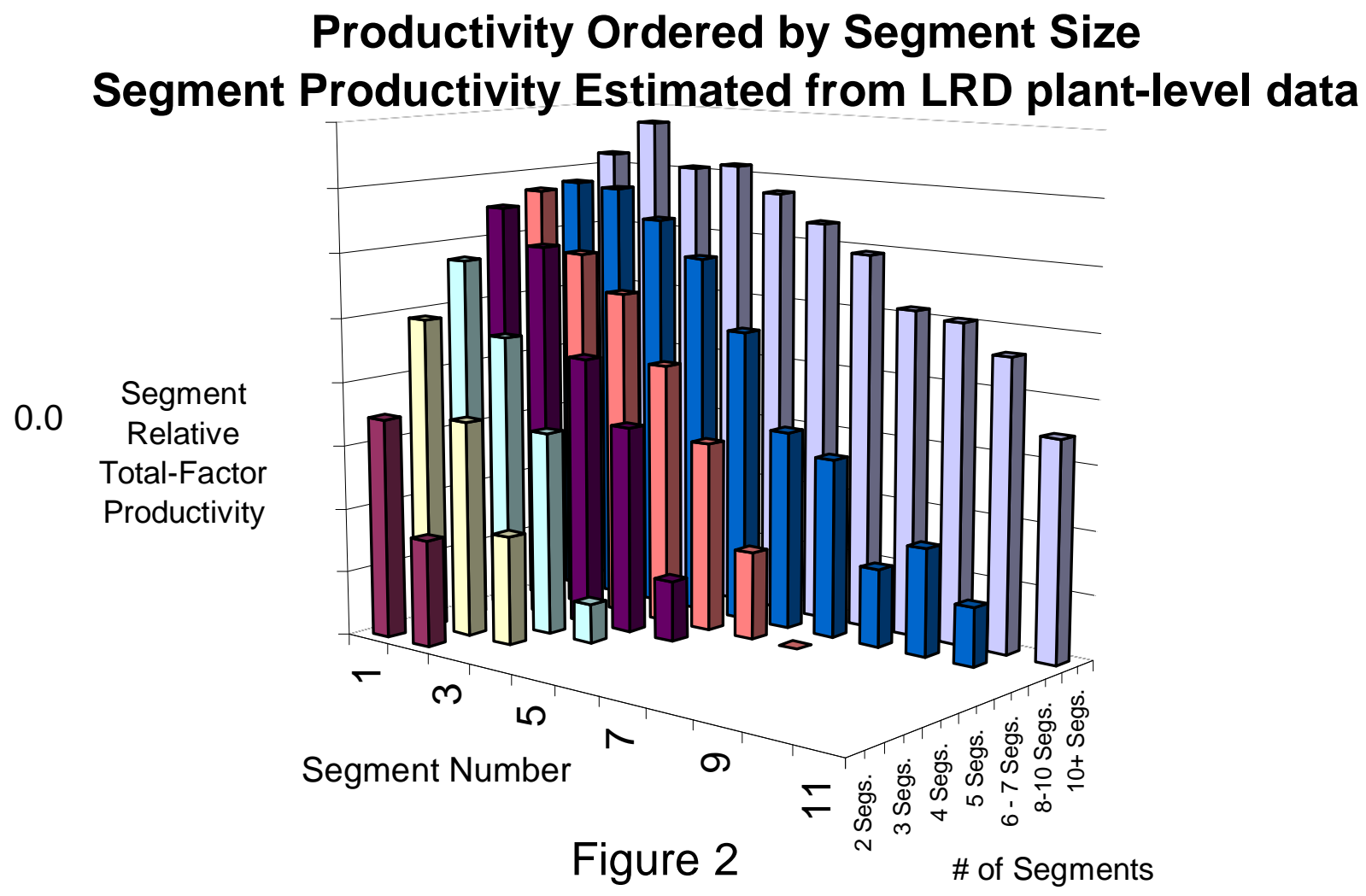




\section{Table I}

\section{Sample Characteristics: Single-Segment and Multiple-Segment Firms}

Sample characteristics of firms' industry operating segments. We calculate statistics from plant-level data aggregated into 3-digit SIC codes for each firm. We classify single-segment versus multiple-segment firms based on 3-digit SIC codes. For multiple-segment firms, main segments are segments that represent at least $25 \%$ of the firm's total shipments. We base size classifications on the previous year's real value of industry shipments relative to each industry's median value of shipments. We determine recession and expansion years using aggregate detrended industrial production. Recession years are years in which both real and detrended industrial production decline relative to the previous year. We classify years as expansion years when both real and detrended industrial production increase relative to the previous year.

\begin{tabular}{|c|c|c|c|}
\hline \multicolumn{4}{|c|}{ Sample of Firms } \\
\hline & $\begin{array}{c}\text { Single-Segment } \\
\text { Firms } \\
\end{array}$ & \multicolumn{2}{|c|}{ Multiple-Segment Firms } \\
\hline \multicolumn{4}{|l|}{ Total Number of Firms } \\
\hline Number of firms beginning of decade: 1980 & 13298 & 1929 & \\
\hline Number of firms end of decade: 1990 & 17321 & 2357 & \\
\hline Statistics by Industry Segments & & Main Segments & Peripheral Segments \\
\hline Number of segments - beginning of decade: 1980 & 13298 & 4880 & 2582 \\
\hline Number of segments - end of decade: 1990 & 17321 & 4745 & 3090 \\
\hline \multicolumn{4}{|c|}{ Proportion of Value of Shipments (All manufacturing industries) } \\
\hline Beginning of decade: 1980 & $21.71 \%$ & $50.75 \%$ & $27.53 \%$ \\
\hline End of decade: 1990 & $26.72 \%$ & $49.65 \%$ & $23.63 \%$ \\
\hline \multicolumn{4}{|l|}{ Average Annual Industry Segment Growth Rate } \\
\hline \multicolumn{4}{|l|}{ Recession years (1981-1982, 1990-1991) } \\
\hline All industry segments & $-5.15 \%$ & $-0.01 \%$ & $-5.48 \%$ \\
\hline $\begin{array}{l}\text { Firms' most productive segments }{ }^{\text {a }} \\
\text { (top 50th percentile of TFP by industry) }\end{array}$ & $-3.54 \%$ & $1.57 \%$ & $-4.06 \%$ \\
\hline \multicolumn{4}{|l|}{ Expansion years (1976-1978, 1984-1988) } \\
\hline All industry segments & $2.46 \%$ & $7.30 \%$ & $2.60 \%$ \\
\hline $\begin{array}{l}\text { Firms' most productive segments }{ }^{\mathrm{a}} \\
\text { (top 50th percentile of TFP by industry) }\end{array}$ & $5.99 \%$ & $9.66 \%$ & $4.35 \%$ \\
\hline
\end{tabular}

${ }^{a}$ Productivity is total factor productivity (TFP) and is a relative measure of productivity. TFPs are standardized by dividing each TFP by the standard deviation of the industry's TFP at the 3-digit level. 


\section{Table II}

\section{Growth and Productivity over the Business Cycle: Expansion Years}

Sample characteristics of firms' industry operating segments in expansion years. We calculate statistics from plant-level data aggregated into 3-digit SIC codes for each firm. We classify single-segment versus multiple-segment firms based on 3-digit SIC codes. For multiple-segment firms, main segments are segments that represent at least $25 \%$ of the firm's total shipments. We base size classifications on the previous year's real value of industry shipments relative to each industry's median value of shipments. Number of segments is for the beginning of the period. We classify years as expansion years when both real and detrended industrial production increase relative to the previous year.

\begin{tabular}{|c|c|c|c|c|c|}
\hline & \multicolumn{3}{|c|}{ Sample of Firms } & & \\
\hline & \multirow{2}{*}{\multicolumn{2}{|c|}{$\begin{array}{c}\text { Single-Segment } \\
\text { Firms } \\
\end{array}$}} & \multicolumn{2}{|c|}{ Multiple-Segment Firms } & \\
\hline & & & Main Segments & Peripheral Seg & nents \\
\hline \multicolumn{6}{|c|}{ Characteristics of firm operating segments in expansion years (average over 1976-1978, 1984-1988) } \\
\hline \multicolumn{6}{|c|}{ Size Group 1: One-quarter to one-half of the industry median } \\
\hline Average real growth of firm segment(s) & $5.10 \%$ & & $9.44 \%$ & $2.97 \%$ & \multirow{4}{*}{$\mathrm{b}$} \\
\hline Growth of efficient segments (top 50\% of TFP) ${ }^{c}$ & $13.70 \%$ & & $17.20 \%$ & $11.40 \%$ & \\
\hline Average productivity (TFP) of firm segment(s) ${ }^{c}$ & -0.200 & & -0.121 & -0.391 & \\
\hline Number of firm segments & 2025 & & 213 & 65 & \\
\hline \multicolumn{6}{|l|}{ Size Group 2: One-half to 1 times the industry median } \\
\hline Average real growth of firm segment(s) & $3.44 \%$ & & $8.63 \%$ & $1.86 \%$ & \multirow{4}{*}{$\mathrm{b}$} \\
\hline Growth of efficient segments (top $50 \%$ of TFP) ${ }^{c}$ & $9.89 \%$ & & $13.80 \%$ & $7.95 \%$ & \\
\hline Average productivity (TFP) of firm segment(s) ${ }^{c}$ & 0.019 & a & 0.015 & -0.298 & \\
\hline Number of firm segments & 1980 & & 362 & 188 & \\
\hline \multicolumn{6}{|l|}{ Size Group 3: 1 to 2 times the industry median } \\
\hline Average real growth of firm segment(s) & $2.13 \%$ & \multirow{4}{*}{$\mathrm{a}$} & $9.08 \%$ & $2.30 \%$ & \multirow{4}{*}{$\mathrm{b}$} \\
\hline Growth of efficient segments (top 50\% of TFP) ${ }^{c}$ & $7.27 \%$ & & $13.56 \%$ & $7.32 \%$ & \\
\hline Average productivity (TFP) of firm segment(s) ${ }^{c}$ & 0.197 & & 0.120 & -0.173 & \\
\hline Number of firm segments & 1195 & & 412 & 274 & \\
\hline \multicolumn{6}{|l|}{ Size Group 4: 2 to 5 times the industry median } \\
\hline Average real growth of firm segment(s) & $1.43 \%$ & \multirow{4}{*}{ a } & $6.77 \%$ & $3.19 \%$ & \multirow{4}{*}{ b } \\
\hline Growth of efficient segments (top 50\% of TFP) ${ }^{c}$ & $4.82 \%$ & & $9.30 \%$ & $6.25 \%$ & \\
\hline Average productivity (TFP) of firm segment(s) ${ }^{c}$ & 0.323 & & 0.234 & -0.077 & \\
\hline Number of firm segments & 576 & & 547 & 560 & \\
\hline \multicolumn{6}{|l|}{ Size Group 5: greater than 5 times the industry median } \\
\hline Average real growth of firm segment(s) & $1.10 \%$ & & $6.15 \%$ & $4.23 \%$ & \multirow{4}{*}{$\mathrm{b}$} \\
\hline Growth of efficient segments (top 50\% of TFP) ${ }^{\mathrm{c}}$ & $2.67 \%$ & & $7.49 \%$ & $6.70 \%$ & \\
\hline Average productivity (TFP) of firm segment(s) ${ }^{c}$ & 0.422 & a & 0.375 & 0.154 & \\
\hline Number of firm segments & 171 & & 731 & 3241 & \\
\hline
\end{tabular}

\footnotetext{
${ }^{a}$ Significantly different from multiple segment firms at less than the 5\% level using a 2-tailed test for the difference of the mean from 0.

${ }^{\mathrm{b}}$ Significant difference between main and peripheral segments at less than the 5\% level using a 2-tailed test for the difference of the mean from 0.

${ }^{c}$ Productivity is total factor productivity (TFP) and is a relative measure of productivity. TFPs are standardized by dividing each TFP by the standard deviation of the industry's TFP at the 3-digit level.
} 


\section{Table III}

\section{Growth and Productivity over the Business Cycle: Recession Years}

Sample characteristics of firms' industry operating segments in recession years. We calculate statistics from plant-level data aggregated into 3-digit SIC codes for each firm. We classify single-segment versus multiple-segment firms based on 3-digit SIC codes. For multiple-segment firms, main segments are segments that represent at least $25 \%$ of the firm's total shipments. We base size classifications on the previous year's real value of industry shipments relative to each industry's median value of shipments. Number of segments is for the beginning of the period. We classify years as recession years when both real and detrended industrial production decrease relative to the previous year.

\begin{tabular}{lll}
\hline & Sample of Firms \\
\hline Characteristics of firm operating segments in recession years (Average over 1981-1982, 1990-1991) \\
\hline
\end{tabular}

Size Group 1: One-quarter to one-half of the industry median

Average real growth of firm segment(s)

Growth of efficient segments (top 50\% of TFP) ${ }^{c}$

Average productivity (TFP) of firm segment(s) ${ }^{c}$

Number of firm segments

Size Group 2: One-half to 1 times the industry median

Average real growth of firm segment(s)

Growth of efficient segments (top 50\% of TFP) ${ }^{\mathrm{c}}$

Average productivity (TFP) of firm segment(s) ${ }^{c}$

Number of firm segments

Size Group 3: 1 to 2 times the industry median

Average real growth of firm segment(s)

Growth of efficient segments (top 50\% of TFP) ${ }^{\mathrm{c}}$

Average productivity (TFP) of firm segment(s) ${ }^{c}$

Number of firm segments

Size Group 4: 2 to 5 times the industry median

Average real growth of firm segment(s)

Growth of efficient segments (top 50\% of TFP) ${ }^{c}$

Average productivity (TFP) of firm segment(s) ${ }^{c}$

Number of firm segments

Size Group 5: greater than 5 times the industry median

Average real growth of firm segment(s)

Growth of efficient segments (top 50\% of TFP) ${ }^{\mathrm{c}}$

Average productivity (TFP) of firm segment(s) ${ }^{\mathrm{c}}$

Number of firm segments

\begin{tabular}{|c|c|c|c|c|}
\hline$-1.50 \%$ & & $2.16 \%$ & $-2.30 \%$ & \multirow{4}{*}{$\mathrm{b}$} \\
\hline $7.57 \%$ & & $7.31 \%$ & $4.79 \%$ & \\
\hline-0.272 & & -0.169 & -0.582 & \\
\hline 3380 & & 116 & 31 & \\
\hline$-3.93 \%$ & \multirow{4}{*}{$\mathrm{a}$} & $0.64 \%$ & $-6.44 \%$ & \multirow{4}{*}{$\mathrm{b}$} \\
\hline $3.12 \%$ & & $6.49 \%$ & $0.66 \%$ & \\
\hline-0.037 & & -0.076 & -0.481 & \\
\hline 3458 & & 222 & 92 & \\
\hline$-5.10 \%$ & \multirow{4}{*}{$\mathrm{a}$} & $-0.75 \%$ & $-8.10 \%$ & \multirow{4}{*}{$\mathrm{b}$} \\
\hline$-0.03 \%$ & & $4.77 \%$ & $-3.11 \%$ & \\
\hline 0.173 & & 0.061 & -0.198 & \\
\hline 2495 & & 341 & 130 & \\
\hline$-5.50 \%$ & \multirow{4}{*}{$\mathrm{a}$} & $-1.07 \%$ & $-5.35 \%$ & \multirow{4}{*}{$\mathrm{b}$} \\
\hline$-1.90 \%$ & & $1.52 \%$ & $-0.36 \%$ & \\
\hline 0.314 & & 0.188 & -0.131 & \\
\hline 1616 & & 630 & 390 & \\
\hline$-6.20 \%$ & \multirow{4}{*}{$\mathrm{a}$} & $-0.84 \%$ & $-4.20 \%$ & \multirow{4}{*}{$\mathrm{b}$} \\
\hline$-3.16 \%$ & & $0.60 \%$ & $-0.78 \%$ & \\
\hline 0.379 & & 0.373 & 0.175 & \\
\hline 1226 & & 1305 & 3967 & \\
\hline
\end{tabular}

${ }^{a}$ Significantly different from multiple segment firms at less than the 5\% level using a 2-tailed test for the difference of the mean from 0.

${ }^{\mathrm{b}}$ Significant difference between main and peripheral segments at less than the 5\% level using a 2-tailed test for the difference of the mean from 0 .

${ }^{c}$ Productivity is total factor productivity (TFP) and is a relative measure of productivity. TFPs are standardized by dividing each TFP by the standard deviation of the industry's TFP at the 3-digit level. 
Table IV

\section{Firm Industry Segment Growth}

Regressions test the effects of plant-level productivity and industry-level demand on firm industry segment sales growth for single-segment and multiple-segment firms. The dependent variable, firm segment growth, is growth less the industry average for the entire period. Segment size and productivity are industry adjusted in each year. Data are aggregated into firm three-digit SIC codes for industry segments from underlying plant-level data. We estimate the regressions using unbalanced panel regressions allowing for correlated residuals within panel units. Significance tests are conducted using heteroskedasticityconsistent standard errors following Huber-White. Data are yearly from 1975 to 1992. (p-values are in parentheses.)

\begin{tabular}{|c|c|c|c|c|}
\hline \multirow[b]{2}{*}{ Variable } & \multicolumn{3}{|c|}{ Dependent Variable: Firm Industry Segment Growth } & \multirow{2}{*}{$\begin{array}{l}\text { Test for Significant Diff.: } \\
\text { Multiple Segment Interaction } \\
\text { Variable (p-value) }^{\text {h }}\end{array}$} \\
\hline & $\begin{array}{r}\text { All Firms } \\
\text { Industry Segments } \\
\end{array}$ & $\begin{array}{r}\text { Single } \\
\text { Segment Firms } \\
\end{array}$ & $\begin{array}{r}\text { Multiple } \\
\text { Segment Firms }\end{array}$ & \\
\hline Constant & $\begin{array}{l}-0.052 \\
(.000)^{\mathrm{a}}\end{array}$ & $\begin{array}{l}0.039 \\
(.002)^{\mathrm{a}}\end{array}$ & $\begin{array}{l}-0.123 \\
(.000)^{\mathrm{a}}\end{array}$ & $(.000)^{\mathrm{a}}$ \\
\hline Industry Returns to Scale $(\lambda)^{d}$ & $\begin{array}{l}0.092 \\
(.000)^{\mathrm{a}}\end{array}$ & $\begin{array}{l}0.036 \\
(.010)^{\mathrm{a}}\end{array}$ & $\begin{array}{l}0.194 \\
(.000)^{\mathrm{a}}\end{array}$ & $(.000)^{\mathrm{a}}$ \\
\hline $\begin{array}{l}\text { Change in aggregate industry } \\
\text { shipments }\end{array}$ & $\begin{array}{l}0.688 \\
(.000)^{\mathrm{a}}\end{array}$ & $\begin{array}{l}0.627 \\
(.000)^{\mathrm{a}}\end{array}$ & $\begin{array}{l}0.805 \\
(.000)\end{array}$ & $(.000)^{\mathrm{a}}$ \\
\hline Firm segment productivity (TFP) ${ }^{\mathrm{e}}$ & $\begin{array}{l}0.079 \\
(.000)^{\mathrm{a}}\end{array}$ & $\begin{array}{l}0.081 \\
(.000)^{\mathrm{a}}\end{array}$ & $\begin{array}{l}0.084 \\
(.000)^{\mathrm{a}}\end{array}$ & $(.013)^{\mathrm{b}}$ \\
\hline Change in Shipments*TFP & $\begin{array}{l}0.041 \\
(.002)^{\mathrm{a}}\end{array}$ & $\begin{array}{l}0.051 \\
(.001)^{\mathrm{a}}\end{array}$ & $\begin{array}{l}0.009 \\
(.717)\end{array}$ & $(.115)$ \\
\hline $\begin{array}{l}\ln (\text { lagged firm segment size }) \\
\quad(\text { coefficient*10,000,000) }\end{array}$ & $\begin{array}{r}-0.002 \\
(.264)\end{array}$ & $\begin{array}{l}0.172 \\
(.000)^{\mathrm{a}}\end{array}$ & $\begin{array}{l}-0.004 \\
(.032)^{b}\end{array}$ & $(.000)^{\mathrm{a}}$ \\
\hline $\begin{array}{l}\text { Number of plants owned by firm } \\
\text { (beginning of year, coeff*1,000) }\end{array}$ & $\begin{array}{l}-0.314 \\
(.000)^{\mathrm{a}}\end{array}$ & $\begin{array}{r}-23.290 \\
(.000)^{\mathrm{a}}\end{array}$ & $\begin{array}{l}-0.279 \\
(.000)^{\mathrm{a}}\end{array}$ & $(.000)^{\mathrm{a}}$ \\
\hline \multicolumn{5}{|l|}{ Firm Multiple Segment Variables } \\
\hline Other segment's weighted TFP ${ }^{\mathrm{f}}$ & $\begin{array}{l}-0.007 \\
(.002)^{\mathrm{a}}\end{array}$ & & $\begin{array}{l}-0.008 \\
(.000)^{\mathrm{a}}\end{array}$ & \\
\hline $\begin{array}{l}\text { Relative demand }{ }^{*} \text { other segments } \\
\text { weighted TFP }\end{array}$ & $\begin{array}{l}-0.006 \\
(.006)^{\mathrm{a}}\end{array}$ & & $\begin{array}{l}-0.008 \\
(.001)^{\mathrm{a}}\end{array}$ & \\
\hline $\begin{array}{l}\text { Other segment's weighted } \\
\text { Returns to Scale }(\lambda)^{\mathrm{f}}\end{array}$ & $\begin{array}{l}-0.023 \\
(.000)^{\mathrm{a}}\end{array}$ & & $\begin{array}{l}-0.051 \\
(.000)^{\mathrm{a}}\end{array}$ & \\
\hline Total Industry Segment Years & 400,046 & 251,927 & 148,119 & \\
\hline Chi - Squared Statistic & 12257.56 & 8977.01 & 4396.03 & \\
\hline Significance Level (p-value) & $<1 \%$ & $<1 \%$ & $<1 \%$ & \\
\hline
\end{tabular}

a, b, c : Significantly different from 0 at the $1 \%, 5 \%$, and $10 \%$ levels, respectively, using a 2-tailed test.

${ }^{\mathrm{d}}$ Returns to scale, $\lambda$, is calculated at the three-digit industry segment level by imposing homogeneity of degree $\lambda$ to input demand equations when estimating a translog production function.

${ }^{\mathrm{e}}$ Total Factor Productivity (TFP) is calculated using a translog production function.

f Other segments' productivity (and returns to scale) are weighted averages of the firm's other segment(s) weighted by the segment(s) sales.

${ }^{g}$ Relative industry demand is interacted with other segments' productivity and equals one (zero, minus one) when the segment's change in shipments at the industry level is greater (equal, less) than that of the firm's median segment.

${ }^{\mathrm{h}}$ Signficance test for a multiple-segment dummy variable interacted with each independent variable in a regression with all firm segments. 
Table V

\section{Conglomerate Industry Segment Growth}

Regressions test the effects of plant-level productivity and industry-level demand on firm industry segment sales growth for main divisions ( greater than 25 percent of firm sales) and peripheral segments of multiple segment firms. The dependent variable, firm segment growth, is growth less the industry average for the entire period. Other variables are as defined in Table IV. We estimate the regressions using unbalanced panel regressions allowing for correlated residuals within panel units. Significance tests are conduced using heteroskedasticity-consistent standard errors following Huber-White. Data are aggregated into firm three digit industry segments from underlying plant-level data with yearly observations from 1975 to 1992 . (p-values are in parentheses.)

\begin{tabular}{|c|c|c|c|}
\hline \multicolumn{3}{|c|}{ Dependent Variable: Firm Industry Segment Growth } & \multirow{3}{*}{$\begin{array}{l}\text { Test for Significant Diff. } \\
\text { Main - Peripheral Segment } \\
\text { Firms (p-value) }\end{array}$} \\
\hline \multirow[b]{2}{*}{ Variable } & \multicolumn{2}{|c|}{ Multiple Segment Firms } & \\
\hline & Main Segment(s) & Peripheral Segment(s) & \\
\hline Constant & $\begin{array}{l}-0.077 \\
(.035)^{\mathrm{b}}\end{array}$ & $\begin{array}{l}-0.274 \\
(.000)^{\mathrm{a}}\end{array}$ & $(.075)^{\mathrm{c}}$ \\
\hline Industry Returns to Scale $(\lambda)$ & $\begin{array}{l}0.166 \\
(.000)^{\mathrm{a}}\end{array}$ & $\begin{array}{l}0.151 \\
(.000)^{\mathrm{a}}\end{array}$ & $(.963)$ \\
\hline $\begin{array}{l}\text { Change in aggregate industry } \\
\text { shipments }\end{array}$ & $\begin{array}{l}0.840 \\
(.000)^{\mathrm{a}}\end{array}$ & $\begin{array}{l}0.817 \\
(.000)^{\mathrm{a}}\end{array}$ & $(.624)$ \\
\hline Firm segment productivity (TFP) & $\begin{array}{l}0.064 \\
(.000)^{\mathrm{a}}\end{array}$ & $\begin{array}{l}0.095 \\
(.000)^{\mathrm{a}}\end{array}$ & $(.000)^{\mathrm{a}}$ \\
\hline Change in Shipments*TFP & $\begin{array}{l}-0.070 \\
(.095)^{\mathrm{c}}\end{array}$ & $\begin{array}{l}0.042 \\
(.189)\end{array}$ & $(.032)^{\mathrm{b}}$ \\
\hline $\begin{array}{l}\ln (\text { lagged firm segment size }) \\
\quad\left(\text { coefficient }^{*} 10,000,000\right)\end{array}$ & $\begin{array}{l}-0.015 \\
(.197)\end{array}$ & $\begin{array}{l}-0.005 \\
(.026)^{b}\end{array}$ & $(.405)$ \\
\hline $\begin{array}{l}\text { Number of plants owned by firm } \\
\text { (beginning of year, coeff* } 1,000 \text { ) }\end{array}$ & $\begin{array}{l}-0.587 \\
(.000)^{\mathrm{a}}\end{array}$ & $\begin{array}{l}0.001 \\
(.974)\end{array}$ & $(.000)^{\mathrm{a}}$ \\
\hline \multicolumn{4}{|l|}{ Firm Multiple Segment Variables } \\
\hline Other segment's weighted TFP & $\begin{array}{l}0.003 \\
(.349)\end{array}$ & $\begin{array}{r}-0.002 \\
(.600)\end{array}$ & $(.190)$ \\
\hline $\begin{array}{l}\text { Relative demand } * \text { other segments } \\
\text { weighted TFP }\end{array}$ & $\begin{array}{l}-0.005 \\
(.060)^{\mathrm{c}}\end{array}$ & $\begin{array}{l}-0.014 \\
(.001)^{\mathrm{a}}\end{array}$ & $(.059)^{\mathrm{c}}$ \\
\hline $\begin{array}{l}\text { Other segment's weighted } \\
\text { Returns to Scale }(\lambda)\end{array}$ & $\begin{array}{l}-0.031 \\
(.003)^{\mathrm{a}}\end{array}$ & $\begin{array}{l}0.122 \\
(.103)\end{array}$ & $(.001)^{\mathrm{a}}$ \\
\hline Total Industry Segment Years & 56,132 & 91,987 & \\
\hline Chi - Squared Statistic & 1701.25 & 2758.86 & \\
\hline Significance Level (p-value) & $<1 \%$ & $<1 \%$ & \\
\hline
\end{tabular}

a, b, c : Significantly different from 0 at the $1 \%, 5 \%$, and $10 \%$ levels, respectively, using a 2 -tailed test. 
Table VI

\section{Economic Significance of Regression Results}

Predicted real growth rates of conglomerate and single-segment firms as productivity and change in shipments varies from the 25 th to the 75 th percentiles. We compute these predicted growth rates holding all variables except productivity and change in industry shipments at their sample medians.

Predicted Real Growth Rates using coefficient estimates from Tables IV and V:

Variables taken at the respective sample medians.

Growth Rate at the:

$\begin{array}{ccc}25 \text { th } & 50 \text { th } & \text { 75th } \\ \text { Percentile } & \text { Percentile } & \text { Percentile }\end{array}$

Varying Total Factor Productivity:

Single-segment Firms (own productivity

Productivity data from conglomerates' main segments

(Both use coefficients from Table 5, column 2)

\section{Conglomerate Firms:}

All Segments

(using coefficients from Table 5, column 3)

Main Segments

$-0.69 \%$

$3.18 \%$

$7.00 \%$

(using coefficients from Table 6, column 1)

Peripheral Segments (own productivity data)

$0.36 \%$

$4.55 \%$

$8.59 \%$

$3.20 \%$

$6.66 \%$

$10.40 \%$

Productivity data from conglomerates' main segments

(Both use coefficients from Table 6, column 2)

\section{Varying Change in Industry Shipments:}

Single-segment Firms (own data):

Data from conglomerates' main segments

$\begin{array}{lll}1.87 \% & 4.55 \% & 7.08 \% \\ 4.02 \% & 6.93 \% & 9.63 \%\end{array}$

(Both use coefficients from Table 5, column 2)

\section{Conglomerate Firms:}

All Segments (own data)

$\begin{array}{lll}-0.72 \% & 3.11 \% & 6.84 \%\end{array}$

(Using coefficients from Table 5, column 3)

Main Segments

$\begin{array}{lll}4.65 \% & 7.32 \% & 10.14 \%\end{array}$

$\begin{array}{lll}-4.26 \% & -0.29 \% & 4.81 \%\end{array}$

$\begin{array}{lll}-3.06 \% & 0.98 \% & 5.34 \%\end{array}$

(using coefficients from Table 6, column 1)

Peripheral Segments

$\begin{array}{lll}3.50 \% & 7.32 \% & 10.80 \% \\ & & \\ -3.66 \% & 0.29 \% & 4.26 \% \\ -3.51 \% & 0.26 \% & 3.75 \%\end{array}$

Shipments data from conglomerates' main segments

$-3.51 \%$

$0.26 \%$

$3.75 \%$

(Both use coefficients from Table 6, column 2) 


\section{Table VII}

\section{Conglomerate Industry Segment Growth in Recession Years}

Regressions test the effects of plant-level productivity and industry-level demand on firm industry segment sales growth for main divisions and peripheral segments of multiple segment firms in recessions. Recession years are 1981, 1982, 1990 and 1991 - identified using detrended and aggregate industrial production.

The dependent variable, firm segment growth, is growth less the industry average for the entire period. Other variables are as defined in Table IV. Data are aggregated into firm three digit industry segments from underlying plant-level data. We estimate the regressions using unbalanced panel regressions allowing for correlated residuals within panel units. Significance tests are conduced using heteroskedasticity-consistent standard errors following Huber-White. Data are yearly from 1975 to 1992 . (p-values are in parentheses.)

\begin{tabular}{|c|c|c|c|}
\hline \multicolumn{3}{|c|}{ Dependent Variable: Firm Industry Segment Growth in Recession Years } & \multirow{3}{*}{$\begin{array}{l}\text { Test for Significant Diff. } \\
\text { Main - Peripheral Segment } \\
\text { Firms (p-value) }\end{array}$} \\
\hline \multirow[b]{2}{*}{ Variable } & \multicolumn{2}{|c|}{ Multiple Segment Firms } & \\
\hline & Main Segment(s) & Peripheral Segment(s) & \\
\hline \multirow[t]{2}{*}{ Constant } & -0.046 & -0.187 & \\
\hline & $(.514)$ & $(.218)$ & $(.152)$ \\
\hline \multirow[t]{2}{*}{ Industry Returns to Scale $(\lambda)$} & 0.129 & 0.180 & \\
\hline & $(.079)^{\mathrm{c}}$ & $(.046)^{\mathrm{b}}$ & $(.671)$ \\
\hline \multirow{2}{*}{$\begin{array}{l}\text { Change in aggregate industry } \\
\text { shipments }\end{array}$} & 0.624 & 0.697 & \\
\hline & $(.000)^{\mathrm{a}}$ & $(.000)^{\mathrm{a}}$ & $(.307)$ \\
\hline \multirow[t]{2}{*}{ Firm segment productivity (TFP) } & 0.051 & 0.088 & \\
\hline & $(.000)^{\mathrm{a}}$ & $(.000)^{\mathrm{a}}$ & $(.000)^{\mathrm{a}}$ \\
\hline \multirow[t]{2}{*}{ Change in Shipments*TFP } & -0.139 & 0.167 & \\
\hline & $(.133)$ & $(.024)^{b}$ & $(.010)^{\mathrm{a}}$ \\
\hline \multirow{2}{*}{$\begin{array}{l}\ln (\text { lagged firm segment size }) \\
\quad(\text { coefficient } * 10,000,000)\end{array}$} & -0.031 & -0.011 & \\
\hline & $(.098)^{\mathrm{c}}$ & $(.001)^{\mathrm{a}}$ & $(.321)$ \\
\hline \multirow{2}{*}{$\begin{array}{l}\text { Number of plants owned by firm } \\
\text { (beginning of year, coeff* } 1,000 \text { ) }\end{array}$} & -0.081 & 0.272 & \\
\hline & $(.696)$ & $(.018)^{\mathrm{b}}$ & $(.139)$ \\
\hline \multicolumn{4}{|l|}{ Firm Multiple Segment Variables } \\
\hline \multirow[t]{2}{*}{ Other segment's weighted TFP } & -0.002 & -0.018 & \\
\hline & $(.706)$ & $(.050)^{\mathrm{b}}$ & $(.147)$ \\
\hline \multirow{2}{*}{$\begin{array}{l}\text { Relative demand } * \text { other segments } \\
\text { weighted TFP }\end{array}$} & -0.003 & -0.012 & \\
\hline & $(.633)$ & $(.167)$ & $(.367)$ \\
\hline \multirow{2}{*}{$\begin{array}{l}\text { Other segment's weighted } \\
\text { Returns to Scale }(\lambda)\end{array}$} & -0.059 & -0.021 & \\
\hline & $(.018)^{\mathrm{b}}$ & $(.889)$ & $(.018)^{\mathrm{b}}$ \\
\hline Total Industry Segment Years & 12,337 & 18,667 & \\
\hline Chi - Squared Statistic & 259.86 & 432.65 & \\
\hline Significance Level (p-value) & $<1 \%$ & $<1 \%$ & \\
\hline
\end{tabular}

a, b, c : Significantly different from 0 at the $1 \%, 5 \%$, and $10 \%$ levels, respectively, using a 2-tailed test. 
Table VIII

\section{Peripheral Division Growth in Recession Years}

Regressions test the effects of plant-level productivity and industry-level demand on firm peripheral segment sales growth. Regressions are estimated for peripheral divisions based on the conglomerates main divisions' sensitivity to recessions. High (low) sensitivity main divisions are conglomerates whose main division's industry experiences a change in industry industry shipments in the upper (lower) fiftieth percentile in recession years 1981, 1982, 1990 and 1991.

The dependent variable, firm segment growth, is growth less the industry average for the entire period. Other variables are as defined in Table IV. Data are aggregated into firm three digit industry segments from underlying plant-level data. We estimate the regressions using unbalanced panel regressions allowing for correlated residuals within panel units.

Significance tests are conduced using heteroskedasticity-consistent standard errors following Huber-White. Data are yearly from 1975 to 1992. (p-values are in parentheses.)

\begin{tabular}{|c|c|c|c|}
\hline \multicolumn{3}{|c|}{ Dependent Variable: Peripheral Division Growth in Recession Years } & \multirow{3}{*}{$\begin{array}{l}\text { Test for Significant Diff. } \\
\text { Low - High Sensitivity } \\
\text { Firms (p-value) }\end{array}$} \\
\hline \multirow[b]{2}{*}{ Variable } & \multicolumn{2}{|c|}{$\begin{array}{c}\text { Peripheral Segments } \\
\text { Main Segment(s) Sensitivity to Recession }\end{array}$} & \\
\hline & Low Sensitivity & High Sensitivity & \\
\hline \multirow[t]{2}{*}{ Constant } & -0.204 & -0.234 & \\
\hline & $(.262)$ & $(.393)$ & $(.709)$ \\
\hline Industry Returns to Scale $(\lambda)$ & $\begin{array}{l}0.129 \\
(.331)\end{array}$ & $\begin{array}{l}0.248 \\
(.042)^{\mathrm{b}}\end{array}$ & $(.504)$ \\
\hline $\begin{array}{l}\text { Change in aggregate industry } \\
\text { shipments }\end{array}$ & $\begin{array}{l}0.754 \\
(.000)^{\mathrm{a}}\end{array}$ & $\begin{array}{l}0.670 \\
(.000)^{\mathrm{a}}\end{array}$ & $(.513)$ \\
\hline Firm segment productivity (TFP) & $\begin{array}{l}0.095 \\
(.000)^{\mathrm{a}}\end{array}$ & $\begin{array}{l}0.081 \\
(.000)^{\mathrm{a}}\end{array}$ & $(.262)$ \\
\hline Change in Shipments*TFP & $\begin{array}{l}0.322 \\
(.011)^{b}\end{array}$ & $\begin{array}{l}0.047 \\
(.589)\end{array}$ & $(.077)^{\mathrm{c}}$ \\
\hline $\begin{array}{l}\ln (\text { lagged firm segment size }) \\
\quad(\text { coefficient } * 10,000,000)\end{array}$ & $\begin{array}{l}-0.045 \\
(.012)^{b}\end{array}$ & $\begin{array}{l}-0.008 \\
(.021)^{\mathrm{b}}\end{array}$ & $(.048)^{\mathrm{b}}$ \\
\hline $\begin{array}{l}\text { Number of plants owned by firm } \\
\text { (beginning of year, coeff* } 1,000 \text { ) }\end{array}$ & $\begin{array}{l}0.744 \\
(.007)^{\mathrm{a}}\end{array}$ & $\begin{array}{l}0.121 \\
(.382)\end{array}$ & $(.057)^{\mathrm{c}}$ \\
\hline \multicolumn{4}{|l|}{ Firm Multiple Segment Variables } \\
\hline Other segment's weighted TFP & $\begin{array}{l}-0.029 \\
(.033)^{b}\end{array}$ & $\begin{array}{r}-0.005 \\
(.684)\end{array}$ & $(.201)$ \\
\hline $\begin{array}{l}\text { Relative demand * other segments } \\
\text { weighted TFP }\end{array}$ & $\begin{array}{r}-0.016 \\
(.214)\end{array}$ & $\begin{array}{r}-0.013 \\
(.272)\end{array}$ & $(.925)$ \\
\hline Other segment's weighted & 0.047 & -0.041 & \\
\hline Returns to Scale $(\lambda)$ & $(.764)$ & $(.891)$ & $(.818)$ \\
\hline Total Industry Segment Years & 9,641 & 9,026 & \\
\hline Chi - Squared Statistic & 235.92 & 208.77 & \\
\hline Significance Level (p-value) & $<1 \%$ & $<1 \%$ & \\
\hline
\end{tabular}

a, b, c : Significantly different from 0 at the $1 \%, 5 \%$, and $10 \%$ levels, respectively, using a 2-tailed test. 


\section{Table IX}

\section{Economic Significance in Recessions}

Predicted real growth rates of conglomerate and single-segment firms as productivity and change in shipments varies from the 25 th to the 75 th percentiles. We compute these predicted growth rates holding all variables except productivity and change in industry shipments at their sample medians.

Predicted Real Growth Rates using coefficient estimates from Tables VII and VIII:

Variables taken at the respective sample medians.

\begin{tabular}{lccc}
\cline { 2 - 4 } Growth Rate at the: & 25 th & 50 th & 75 th \\
& Percentile & Percentile & Percentile \\
\hline
\end{tabular}

\section{Varying Total Factor Productivity:}

\section{Conglomerate Firms:}

Main Segments

(using coefficients from Table 8, column 1)

Peripheral Segments (own productivity data)

(using coefficients from Table 8, column 2)

Peripheral segments (productivity data from main segmen

Peripheral Segments with:

Parent main division less sensitive to recessions (using coefficients from Table 9, column 1)

Parent main division more sensitive to recessions (using coefficients from Table 9, column 2)

\section{Varying Change in Industry Shipments:}

\section{Conglomerate Firms:}

Main Segments

(using coefficients from Table 8, column 1)

Peripheral Segments (own shipments data)

(using coefficients from Table 8, column 2)

Peripheral segments (shipments data from main segments

$\begin{array}{lll}-0.47 \% & 1.97 \% & 4.05 \% \\ -7.07 \% & -4.17 \% & -0.01 \% \\ -6.88 \% & -3.88 \% & -1.43 \% \\ -5.90 \% & -3.19 \% & -0.40 \% \\ -7.61 \% & -4.90 \% & -2.21 \%\end{array}$

Peripheral Segments with:

Parent main division less sensitive to recessions (using coefficients from Table 9, column 1)

Parent main division more sensitive to recessions (using coefficients from Table 9, column 2)

\section{$4.55 \%$}

$\begin{array}{lll}-8.37 \% & -4.17 \% & -0.01 \%\end{array}$

$\begin{array}{lll}-7.49 \% & -3.78 \% & 0.30 \%\end{array}$

$\begin{array}{lll}-7.79 \% & -3.19 \% & 1.40 \%\end{array}$

$\begin{array}{lll}-8.79 \% & -4.90 \% & -1.13 \%\end{array}$ 
Table X

\section{Conglomerate Firms that Become Single Segement Firms}

Regressions test the effects of firm and industry-level variables on segment sales growth for conglomerate firms that become single industry segment firms. The dependent variable, firm segment growth, is growth less the industry average for the entire period. Other variables are as defined in Table IV. We estimate the regressions using unbalanced panel regressions allowing for correlated residuals within panel units. Significance tests are conduced using heteroskedasticity-consistent standard errors following Huber-White. Data are aggregated into firm three digit industry segments from underlying plant-level data with yearly observations from 1975 to 1992 . (p-values are in parentheses.)

\begin{tabular}{|c|c|c|c|c|}
\hline \multicolumn{5}{|c|}{ Dependent Variable: Firm Industry Segment Growth } \\
\hline & $\begin{array}{r}\text { Conglomerate F } \\
\text { Single Seg } \\
\text { onglomerate Period }\end{array}$ & $\begin{array}{l}\text { irms that Become } \\
\text { gment Firms } \\
\text { Single Segment Period }\end{array}$ & $\begin{array}{l}\text { Firms that remain } \\
\text { Conglomerates }\end{array}$ & $\begin{array}{l}\text { Test for Significant Diff } \\
\text { Column } 1 \text { - Column } 3 \\
\text { (p-value) }\end{array}$ \\
\hline \multirow{2}{*}{ Constant } & -.286 & -.183 & -.184 & \\
\hline & $(.000)^{\mathrm{a}}$ & $(.001)^{\mathrm{a}}$ & $(.000)^{\mathrm{a}}$ & $(.000)^{\mathrm{a}}$ \\
\hline \multirow{2}{*}{ Industry Returns to Scale $(\lambda)$} & .137 & .274 & .207 & \\
\hline & $(.014)^{\mathrm{b}}$ & $(.000)^{\mathrm{a}}$ & $(.000)^{\mathrm{a}}$ & $(.247)$ \\
\hline \multirow{2}{*}{$\begin{array}{l}\text { Change in aggregate industry } \\
\text { shipments }\end{array}$} & .807 & .812 & .815 & \\
\hline & $(.000)^{\mathrm{a}}$ & $(.000)^{\mathrm{a}}$ & $(.000)^{\mathrm{a}}$ & $(.773)$ \\
\hline \multirow{2}{*}{ Firm segment productivity (TFP) } & .096 & .090 & .080 & \\
\hline & $(.000)^{\mathrm{a}}$ & $(.000)^{\mathrm{a}}$ & $(.000)^{\mathrm{a}}$ & $(.011)^{\mathrm{b}}$ \\
\hline \multirow[t]{2}{*}{ Change in Shipments*TFP } & -.048 & .057 & .010 & \\
\hline & $(.418)$ & $(.417)$ & $(.729)$ & $(.325)$ \\
\hline \multirow{2}{*}{$\begin{array}{l}\ln (\text { lagged firm segment size }) \\
\quad(\text { coefficient } * 10,000,000)\end{array}$} & -.028 & .163 & -.004 & \\
\hline & $(.540)$ & $(.018)^{\mathrm{b}}$ & $(.043)^{\mathrm{b}}$ & $(.583)$ \\
\hline $\begin{array}{l}\text { Number of plants owned by firm } \\
\text { (beginning of year, coeff* } 1,000 \text { ) }\end{array}$ & $\begin{array}{l}-.515 \\
(.040)^{b}\end{array}$ & $\begin{array}{r}-23.717 \\
(.000)^{\mathrm{a}}\end{array}$ & $\begin{array}{c}-.251 \\
(.000)^{\mathrm{a}}\end{array}$ & $(.319)$ \\
\hline \multicolumn{5}{|l|}{ Firm Multiple Segment Variables } \\
\hline \multirow[t]{2}{*}{ Other segment's weighted TFP } & .000 & & -.014 & \\
\hline & $(.987)$ & & $(.000)^{\mathrm{a}}$ & $(.004)^{\mathrm{a}}$ \\
\hline \multirow{2}{*}{$\begin{array}{l}\text { Relative demand * other segments } \\
\text { weighted TFP }\end{array}$} & .000 & & -.012 & \\
\hline & $(.987)$ & & $(.000)^{\mathrm{a}}$ & $(.021)^{\mathrm{b}}$ \\
\hline \multirow{2}{*}{$\begin{array}{l}\text { Other segment's weighted } \\
\text { Returns to Scale }(\lambda)\end{array}$} & .166 & & .001 & \\
\hline & $(.009)^{\mathrm{a}}$ & & $(.973)$ & $(.026)^{b}$ \\
\hline Total Industry Segment Years & 23,778 & 19,944 & 105,390 & \\
\hline Total Firms & 1,228 & & 1,747 & \\
\hline Chi - Squared Statistic & 941.95 & 570.41 & 3082.18 & \\
\hline Significance Level (p-value) & $<1 \%$ & $<1 \%$ & $<1 \%$ & \\
\hline
\end{tabular}

a, b, c : Significantly different from 0 at the $1 \%, 5 \%$, and $10 \%$ levels, respectively, using a 2-tailed test. 


\section{Table XI}

Robustness Tests: Including Industry Cash Flow

Regressions include industry-level cashflow to test the robustness of prior results to alternative measures of the potential for inefficient resource allocation. We include both industry cashflow for the segment in question and for the firm's other segments. We interact the industry cashflow of the other firm's segment(s) with the weighted productivity of these segments. As before, the dependent variable, firm segment growth, is growth less the industry average for the entire period. Other variables are as defined in Table IV. Data are aggregated into firm three digit industry segments from underlying plant-level data. We estimate the regressions using unbalanced panel regressions allowing for correlated residuals within panel units.

Significance tests are conduced using heteroskedasticity-consistent standard errors following Huber-White. Data are yearly from 1975 to 1992. (p-values are in parentheses.)

\begin{tabular}{|c|c|c|c|c|}
\hline \multicolumn{5}{|c|}{ Dependent Variable: Firm Industry Segment Growth } \\
\hline \multicolumn{4}{|c|}{ Conglomerate Firms that Become } & \multirow{2}{*}{\begin{tabular}{|l} 
Test for Significant Diff. \\
Column 1 - Column 3 \\
(p-value)
\end{tabular}} \\
\hline Cong & lomerate Period & Single Segment Period & Conglomerates & \\
\hline \multirow{2}{*}{ Constant } & 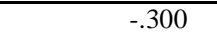 & $\begin{array}{c}-.191 \\
\end{array}$ & 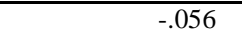 & \\
\hline & $(.001)^{\mathrm{a}}$ & $(.006)^{\mathrm{a}}$ & $(.219)$ & $(.013)^{\mathrm{a}}$ \\
\hline \multirow[t]{2}{*}{ Industry Returns to Scale $(\lambda)$} & .128 & .281 & .208 & \\
\hline & $(.036)$ & $(.000)^{\mathrm{a}}$ & $(.000)^{\mathrm{a}}$ & $(.231)$ \\
\hline \multirow[t]{2}{*}{ Industry Cashflow } & -.011 & .005 & -.001 & \\
\hline & $(.721)$ & $(.865)$ & $(.953)$ & $(.791)$ \\
\hline \multirow{2}{*}{$\begin{array}{l}\text { Change in aggregate industry } \\
\text { shipments }\end{array}$} & .806 & .812 & .817 & \\
\hline & $(.000)^{\mathrm{a}}$ & $(.000)^{\mathrm{a}}$ & $(.000)^{\mathrm{a}}$ & $(.716)$ \\
\hline \multirow[t]{2}{*}{ Firm segment productivity (TFP) } & .096 & .090 & .081 & \\
\hline & $(.000)^{\mathrm{a}}$ & $(.000)^{\mathrm{a}}$ & $(.000)^{\mathrm{a}}$ & $(.014)^{\mathrm{b}}$ \\
\hline \multirow[t]{2}{*}{ Change in Shipments*TFP } & -.048 & .057 & .011 & \\
\hline & $(.418)$ & $(.417)$ & $(.702)$ & $(.318)$ \\
\hline \multirow{2}{*}{$\begin{array}{c}\ln (\text { lagged firm segment size }) \\
(\text { coefficient* } 10,000,000)\end{array}$} & -.025 & .164 & -.005 & \\
\hline & $(.585)$ & $(.018)^{\mathrm{b}}$ & $(.016)^{\mathrm{b}}$ & $(.643)$ \\
\hline \multirow{2}{*}{$\begin{array}{l}\text { Number of plants owned by firm } \\
\text { (beginning of year, coeff* } 1,000 \text { ) }\end{array}$} & -.516 & -23.705 & -.273 & \\
\hline & $(.040)^{\mathrm{b}}$ & $(.000)^{\mathrm{a}}$ & $(.000)^{\mathrm{a}}$ & $(.364)$ \\
\hline \multicolumn{5}{|l|}{ Firm Multiple Segment Variables } \\
\hline \multirow[t]{2}{*}{ Other segment's weighted TFP } & -.006 & & .004 & \\
\hline & $(.787)$ & & $(.740)$ & $(.713)$ \\
\hline \multirow{2}{*}{$\begin{array}{l}\text { Relative demand } * \text { other segments } \\
\text { weighted TFP }\end{array}$} & .000 & & -.012 & \\
\hline & $(.977)$ & & $(.000)^{\mathrm{a}}$ & $(.022)^{\mathrm{b}}$ \\
\hline \multirow{2}{*}{$\begin{array}{l}\text { Other segment's weighted } \\
\text { Returns to Scale }(\lambda)\end{array}$} & .185 & & -.097 & \\
\hline & $(.009)^{\mathrm{a}}$ & & $(.013)^{\mathrm{b}}$ & $(.001)^{\mathrm{a}}$ \\
\hline \multirow{2}{*}{$\begin{array}{l}\text { Other segment's weighted } \\
\text { Industry Cashflow }\end{array}$} & .021 & & -.082 & \\
\hline & $(.566)$ & & $(.000)^{\mathrm{a}}$ & $(.010)^{\mathrm{a}}$ \\
\hline \multirow{2}{*}{$\begin{array}{l}\text { Industry Cashflow* other segments } \\
\text { weighted TFP }\end{array}$} & .013 & & -.037 & \\
\hline & $(.783)$ & & $(.194)$ & $(.368)$ \\
\hline Total Industry Segment Years & 23,778 & 19,944 & 105,390 & \\
\hline Total Firms & 1,228 & & 1,747 & \\
\hline Chi - Squared Statistic & 943.72 & 570.77 & 3136.79 & \\
\hline Significance Level (p-value) & $<1 \%$ & $<1 \%$ & $<1 \%$ & \\
\hline
\end{tabular}

a, b, c : Significantly different from 0 at the $1 \%, 5 \%$, and $10 \%$ levels, respectively, using a 2 -tailed test. 